Atmos. Chem. Phys., 10, 2691-2708, 2010

www.atmos-chem-phys.net/10/2691/2010/

(C) Author(s) 2010. This work is distributed under

the Creative Commons Attribution 3.0 License.

\title{
Atmospheric nitrogen budget in Sahelian dry savannas
}

\author{
C. Delon ${ }^{1}$, C. Galy-Lacaux ${ }^{1}$, A. Boone ${ }^{2}$, C. Liousse ${ }^{1}$, D. Serça ${ }^{1}$, M. Adon ${ }^{1,3}$, B. Diop ${ }^{4}$, A. Akpo ${ }^{5}$, F. Lavenu ${ }^{6, \dagger}$, \\ E. Mougin ${ }^{6}$, and F. Timouk ${ }^{6}$ \\ ${ }^{1}$ Laboratoire d'Aérologie, Université de Toulouse and CNRS, Toulouse, France \\ ${ }^{2} \mathrm{CNRM} / \mathrm{GMME}$, Météo-France, Toulouse, France \\ ${ }^{3}$ Laboratoire de Physique de l'Atmosphere, Abidjan, Côte d'Ivoire \\ ${ }^{4}$ Université de Bamako, Mali \\ ${ }^{5}$ Université Abomey Calavi, Cotonou, Bénin \\ ${ }^{6}$ CESBIO, Toulouse, France \\ $\dagger$ deceased
}

Received: 30 April 2009 - Published in Atmos. Chem. Phys. Discuss.: 30 June 2009

Revised: 5 March 2010 - Accepted: 9 March 2010 - Published: 23 March 2010

\begin{abstract}
The atmospheric nitrogen budget depends on emission and deposition fluxes both as reduced and oxidized nitrogen compounds. In this study, a first attempt at estimating the Sahel nitrogen budget for the year 2006 is made, through measurements and simulations at three stations from the IDAF network situated in dry savanna ecosystems. Dry deposition fluxes are estimated from measurements of $\mathrm{NO}_{2}$, $\mathrm{HNO}_{3}$ and $\mathrm{NH}_{3}$ gaseous concentrations and from simulated dry deposition velocities, and wet deposition fluxes are calculated from $\mathrm{NH}_{4}^{+}$and $\mathrm{NO}_{3}^{-}$concentrations in samples of rain. Emission fluxes are estimated including biogenic emission of NO from soils (an Artificial Neural Network module has been inserted into the ISBA-SURFEX surface model), emission of $\mathrm{NO}_{\mathrm{x}}$ and $\mathrm{NH}_{3}$ from domestic fires and biomass burning, and volatilization of $\mathrm{NH}_{3}$ from animal excreta. Uncertainties are calculated for each contribution of the budget.

This study uses original and unique data from remote and hardly-ever-explored regions. The monthly evolution of oxidized $\mathrm{N}$ compounds shows that emission and deposition increase at the beginning of the rainy season because of large emissions of biogenic NO (pulse events). Emission of oxidized compounds is dominated by biogenic emission from soils (domestic fires and biomass burning of oxidized compounds account for 0 to $13 \%$ at the most at the annual scale, depending on the station), whereas emission of $\mathrm{NH}_{3}$ is dominated by the process of volatilization from soils. At the annual scale, the average gaseous dry deposition accounts
\end{abstract}

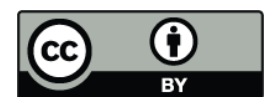

Correspondence to: C. Delon (claire.delon@aero.obs-mip.fr) for $47 \%$ of the total estimated deposition flux, for both oxidized and reduced compounds. The average estimated wet plus dry deposition flux in dry savanna ecosystems is $7.5 \pm 1.8 \mathrm{kgNha}^{-1} \mathrm{yr}^{-1}$, with approximately $30 \%$ attributed to oxidized compounds, and the rest attributed to $\mathrm{NH}_{\mathrm{x}}$. The average estimated emission flux ranges from $8.4( \pm 3.8)$ to $12.4( \pm 5.9) \mathrm{kgNha}^{-1} \mathrm{yr}^{-1}$, dominated by $\mathrm{NH}_{3}$ volatilization (72-82\%) and biogenic emission from soils (11-17\%), depending on the applied volatilization rate of $\mathrm{NH}_{3}$. While larger, emission fluxes are on the same order of magnitude as deposition fluxes. The main uncertainties are linked to the $\mathrm{NH}_{3}$ emission from volatilization.

When scaled up from the 3 measurement sites to the Sahelian region $\left(12^{\circ} \mathrm{N}: 18^{\circ} \mathrm{N}, 15^{\circ} \mathrm{W}: 10^{\circ} \mathrm{E}\right)$, the estimated total emission ranges from $2( \pm 0.9)$ to $3( \pm 1.4) \mathrm{TgNyr}^{-1}$, depending on the applied volatilization rate of $\mathrm{NH}_{3}$ and estimated total deposition is $1.8( \pm 0.4) \mathrm{TgNyr}^{-1}$. The dry savanna ecosystems of the Sahel contribute around $2 \%$ to the global (biogenic + anthropogenic) nitrogen budget.

\section{Introduction}

Nitrogen is a key compound both as a nutrient for plants and animals and as an atmospheric pollutant. In the atmosphere, several nitrogen trace compounds are present, such as $\mathrm{NO}$, $\mathrm{NO}_{2}, \mathrm{HNO}_{3}, \mathrm{~N}_{2} \mathrm{O}$ and $\mathrm{NH}_{3}$, as well as particulate and aqueous forms such as $\mathrm{NO}_{3}^{-}$and $\mathrm{NH}_{4}^{+}$. At the global scale, the reactive $\mathrm{N}$ cycle has been widely impacted by human activities, notably for food production. Indeed, the creation of reactive nitrogen has increased by $120 \%$ since 1970 and

Published by Copernicus Publications on behalf of the European Geosciences Union. 
reached $187 \mathrm{TgNyr}^{-1}$ in 2005 , which is a consequence of the increase of the world population (Galloway et al., 2008). Anthropogenic emissions of $\mathrm{NO}_{\mathrm{x}}$ are better quantified than natural emissions, and $\mathrm{NH}_{3}$ emissions from all sources and at all scales remain largely uncertain (Sutton et al., 2007). Nitrogen emissions from the soil contribute to the formation of the above mentioned gaseous products, whereas enrichment of nitrogen in the soil will take place through biological nitrogen fixation, nitrogen wet and dry deposition or nitrogen fertilization (Vlek, 1981). Reactive Nitrogen emissions from soils are influenced by several environmental and physical parameters, such as soil temperature and moisture, soil $\mathrm{pH}$, texture, wind speed, plant cover, floristic composition (e.g. legumes) and $\mathrm{N}$ input (fertilization) (Williams et al., 1992; Yienger and Levy, 1995 and references therein; Potter et al., 1996; Bouwman et al., 2002b; Meixner and Yang, 2004; Delon et al., 2007). In semi arid and arid regions, limited water resources will have significant consequences on nitrogen cycling in the soil and the atmosphere. The maximum emission will occur for an optimal value of the Water Filled Pore Space (WFPS). Above (and below) this optimal value (depending on the type of soil and climate), the emission will decrease. The seasonal rainfall distribution leads to an accumulation of $\mathrm{N}$ in soils during the dry season, and to large pulses of $\mathrm{N}$ emission at the beginning of the rainy season (Austin et al. (2004); Jaeglé et al. (2004)). Resulting emissions from these pulse events release high quantities of $\mathrm{NO}_{\mathrm{x}}$ in the atmosphere, contributing to increased ozone formation in the troposphere and long range transport of ozone. In Sahelian regions, (the part of West Africa defined as $\left(12^{\circ} \mathrm{N}: 18^{\circ} \mathrm{N}, 15^{\circ} \mathrm{W}: 10^{\circ} \mathrm{E}\right)$ nitrogen emissions may come from different sources throughout the year. In this study, we will focus on simulated biogenic soil emissions of $\mathrm{NO}_{\mathrm{x}}$, calculated biomass burning and domestic fuel emissions of $\mathrm{NO}_{\mathrm{x}}$ and $\mathrm{NH}_{3}$, and calculated volatilization of $\mathrm{NH}_{3}$ from animal manure. Neither industrial $\mathrm{N}$ sources nor $\mathrm{N}$ emissions from synthetic fertilization are taken into account because of the remote location of the Sahel from big cities or industrial centres, and because synthetic fertilizers are either used sparingly or not at all in this region of the world. Similar to emission, wet and dry deposition play an essential role in determining the concentration of nitrogen compounds in the atmosphere, and the nitrogen input to the soil/plant system.

The IDAF (IGAC/DEBITS/AFrica) programme started in 1995 with the establishment of 10 measurement sites representative of major African ecosystems. The objectives of the programme are to study dry and wet deposition of important trace species and more generally the biogeochemical cycles of key nutrients. In this way, the IDAF activity is based on high quality measurements of atmospheric chemical data (gaseous, precipitation and aerosol chemical composition) on the basis of a multi-year monitoring. Since 2005, the ORE (Environmental Research Observatory) IDAF has been part of the AMMA (African Monsoon Mutidisciplinary Analyses) EOP (Extensive Observation period) and

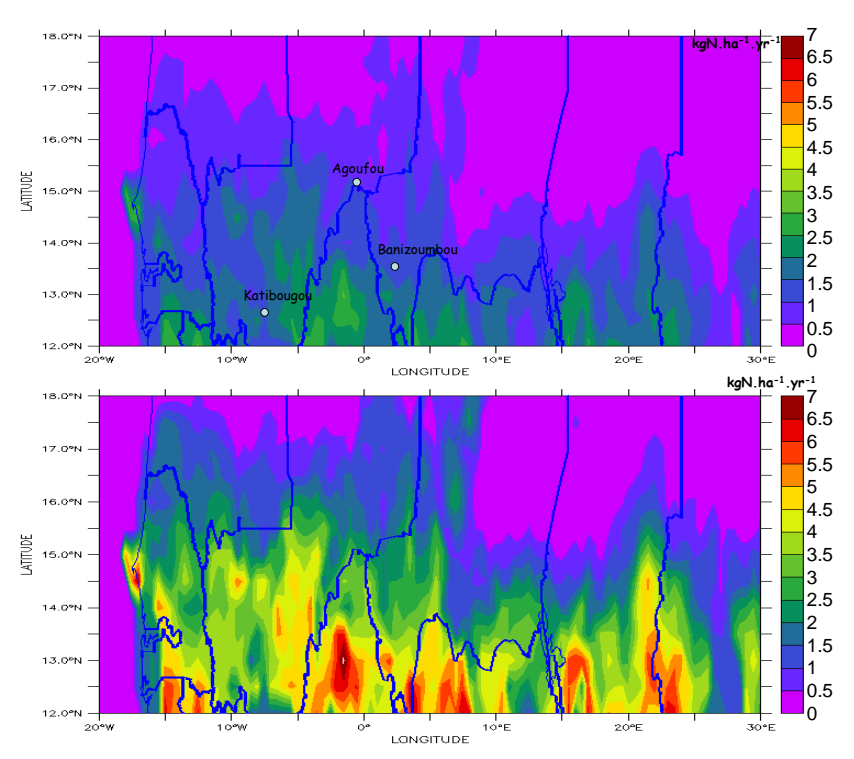

Fig. 1. Simulated biogenic NO flux from soils in $\mathrm{kgNha}^{-1} \mathrm{yr}^{-1}$ in North West Africa (a) annual mean, (b) JJAS mean

LOP (Long Observation period) program in West Africa, and within the SACCLAP program (South African Climate Change Air Pollution- PICS NRF/CNRS) in South Africa. The IDAF network and the resulting scientific research have been presented in several papers, such as Galy-Lacaux and Modi (1998); Galy-Lacaux et al. (2001, 2009); Yoboué et al. (2005); Adon et al. (2010). The objective of this study is the calculation of the balance between $\mathrm{N}$ compounds emission and deposition, in order to quantify the atmospheric nitrogen budget in dry savannas. A focus will be made in 3 study sites which are representative of rural semi-arid savannas: Banizoumbou (Niger, $13.33^{\circ} \mathrm{N}, 2.41^{\circ} \mathrm{E}$ ), Katibougou (Mali, $12.5^{\circ} \mathrm{N}, 7.3^{\circ} \mathrm{W}$ ) and Agoufou (Mali, $15.3^{\circ} \mathrm{N}, 1.5^{\circ} \mathrm{W}$ ), for the year 2006 (see Fig. 1).

In order to calculate $\mathrm{N}$ compound emission and deposition, and to quantify the distribution of different emission sources, methods of calculation of emission and deposition fluxes will be presented. The assumptions made to estimate each contribution will be explained, as well as all sources of uncertainties.

In the following, the budget will be calculated first for oxygenated $\mathrm{N}$ compounds $\left(\mathrm{NO}_{\mathrm{x}}\right.$ for emissions, $\mathrm{NO}_{2}, \mathrm{HNO}_{3}$ and $\mathrm{NO}_{3}^{-}$for deposition) at the monthly and annual scale for the year 2006, and second for $\mathrm{NH}_{\mathrm{x}}$ products $\left(\mathrm{NH}_{3}, \mathrm{NH}_{4}^{+}\right)$at the annual time scales. Not all the nitrogen gaseaous compounds are taken into account in this budget, but the main species are represented and a nitrogen compounds budget will be calculated at the 3 IDAF stations, and scaled up to the Sahelian regional scale $\left(12^{\circ} \mathrm{N}: 18^{\circ} \mathrm{N}, 15^{\circ} \mathrm{W}: 10^{\circ} \mathrm{E}\right)$. 


\section{Material and methods}

\subsection{Deposition}

The IDAF network is the French contribution to the international IGAC (International Global Atmospheric Chemistry)/DEBITS (Deposition of Biogeochemically Important Trace Species) program. The DEBITS committee has defined a set of experimental and analytical protocols to have comparable measurements from all the DEBITS stations. The IDAF network has adopted these protocols as well. Further information on the IDAF network may be found at http://medias.obs-mip.fr/idaf/.

Continuous measurements of $\mathrm{N}$ compounds concentration in air and rain have been performed in Banizoumbou $\left(13.3^{\circ} \mathrm{N}, 2.41^{\circ} \mathrm{E}\right.$, Niger) from 1994 until now, in Agoufou $\left(15.3^{\circ} \mathrm{N}, 1.5^{\circ} \mathrm{W}\right.$, Mali) from 2004 to 2007 , and in Katibougou $\left(12.5^{\circ} \mathrm{N}, 7.3^{\circ} \mathrm{W}\right.$, Mali) from 1997 up to now. Comprehensive descriptions of the stations can be found in Mougin et al. (2009) for Agoufou, in Galy-Lacaux and Modi (1998) for Banizoumbou, and in Adon et al. (2010) for Katibougou. Agoufou and Banizoumbou are part of the AMMA CATCH (Couplage de l'Atmosphère Tropicale et du Cycle Hydrologique) observatory. Banizoumbou is located in a rural and agro pastoral area of the Sahelian region of Niger, approximately at $60 \mathrm{~km}$ from Niamey. Katibougou is located at $60 \mathrm{~km}$ from Bamako. No major source of anthropogenic pollution influences the station. Agoufou is situated towards the northern limit of the area reached by the West African monsoon.

The atmospheric nitrogen deposition budget estimated in this paper is based on experimental measurements for the year 2006. Because of missing data for $\mathrm{NH}_{3}$ concentrations in Agoufou during several months in 2006, a mean value (integrating measurements performed during the years 2005, 2006 and 2007) was used for $\mathrm{NH}_{3}$ dry deposition fluxes estimate in Agoufou.

To estimate atmospheric nitrogen deposition, including both wet and dry processes, we compiled the IDAF nitrogen data from gas and rain chemistry measurements. This study will give the relative contribution of dry and wet deposition processes to the total nitrogen deposition in 2006.

\subsubsection{Dry deposition estimate}

Gaseous measurements $\left(\mathrm{NH}_{3}, \mathrm{HNO}_{3}, \mathrm{NO}_{2}\right)$ are monthly integrated samples using passive sampling techniques following the work of Ferm et al. (1994). This technique has been tested in different tropical and subtropical regions (Ferm and Rodhe, 1997; Carmichael et al., 2003; Martins et al., 2007). All samples of the IDAF west-central African stations are brought to the Laboratory of Aerology (LA) in Toulouse, France, for ionic chromatography analysis. All details and performances of IDAF passive samplers are given in Martins et al. (2007).
At each IDAF station, passive samplers have been exposed monthly in duplicate, at $1.5 \mathrm{~m}$ height. To give an indication of the precision of this sampling technique, the covariance of all duplicate samples were obtained for a ten year period (1998-2007) and found to be $20 \%, 9.8 \%, 14.3 \%$ for $\mathrm{HNO}_{3}, \mathrm{NO}_{2}$ and $\mathrm{NH}_{3}$, respectively. The covariances compare well with those reported by Martins et al. (2007), at the Southern African sites, for the same pollutants $(20 \%, 8.3 \%$, $15.3 \%$, for $\mathrm{HNO}_{3}, \mathrm{NO}_{2}$ and $\mathrm{NH}_{3}$, respectively). The average of the duplicate samplers was used in all cases except when contamination of one of the samplers was suspected (this happened in less than $5 \%$ of all data). The detection limit of the passive samplers was evaluated with the variations in the blank amounts of the impregnated filters and found to be $0.05( \pm 0.03) \mathrm{ppb}$ for $\mathrm{HNO}_{3}, 0.2( \pm 0.1) \mathrm{ppb}$ for $\mathrm{NO}_{2}$ and $1( \pm 0.5) \mathrm{ppb}$ for $\mathrm{NH}_{3}$, respectively. For the $\mathrm{HNO}_{3}$, $\mathrm{NO}_{2}$ and $\mathrm{NH}_{3}$ measurements, $12 \%, 4 \%$ and $0 \%$ were below the detection limit, respectively. Adon et al. (2010) presents all the IDAF database from 1998 to 2007 and gives all the details on the samplers, the quality checking and the associated uncertainties. In this study, we used the uncertainty on gas concentrations calculated from the covariance of all duplicate samples. The uncertainties on $\mathrm{HNO}_{3}, \mathrm{NO}_{2}$ and $\mathrm{NH}_{3}$ concentrations are equal to $20 \%, 9.8 \%$ and $14.3 \%$, respectively. However, it has to be noted that using the covariance for the estimated uncertainty of the monthly passive sample measurements does not account for the inaccuracy of these measurements. As such, the uncertainties quoted here are lower than actual.

The monthly estimated dry deposition flux (generally expressed in units of molecules $\mathrm{cm}^{-2} \mathrm{~s}^{-1}$, and converted to $\mathrm{kgNha}^{-1} \mathrm{yr}^{-1}$ here) is computed using the inferential method, which is defined as taking the product of the measured gas concentration in the air (molecules $\mathrm{cm}^{-3}$ ) and the corresponding deposition velocity in $\mathrm{cm} / \mathrm{s}$. The deposition velocity is estimated for each site and species. This method has been widely used in other studies for different types of ecosystems, as in Shen et al. (2009), Pineda and Venegas (2009), Jin et al. (2006), Zhang et al. (2005) and Zhang et al. (2009). The estimate of the gaseous dry nitrogen deposition has been calculated as the sum of the dry deposition flux estimates of ammonia $\left(\mathrm{NH}_{3}\right)$, nitric acid $\left(\mathrm{HNO}_{3}\right)$ and nitrogen oxide $\left(\mathrm{NO}_{2}\right)$.

Dry deposition velocities have been estimated using the Soil Vegetation ATmosphere (SVAT) big-leaf model ISBA (Interactions between Soil Biosphere and Atmosphere, Noilhan and Mahfouf (1996), presented below). In the model the general resistance parameterization for dry deposition velocities of Wesely and Hicks (1977) has been introduced. The surface resistance incorporates both the physical and biological surface characteristics together with the solubility of deposited species (Baer and Nester, 1992). For vegetated surfaces (Wesely, 1989), one further considers the relative contributions of stomata, mesophyllic tissues, and cuticle whereas for liquid surfaces, the parameterization of 
Erisman and Baldocchi (1994) is used. For the cuticle and soil resistances, the parameterization developed Zhang et al. (2003) has been used. These parameterizations have been included in ISBA and coupled with the 255 surface classification types. ISBA calculates such evolving parameters as aerodynamical, quasi-laminar, stomatal resistances, and drag coefficients for different vegetation types. Chemical dry deposition velocities evolve at each time step together with surface wind, turbulent conditions and chemical parameters. Meteorological conditions are provided by the forcing, derived from satellite data, and developed in ALMIP (AMMA Land surface Model Intercomparison Project), described below. Validation of surface temperature and moisture have been made within the ALMIP project (Boone et al. (2009), DeRosnay et al. (2009)). The forcing in ALMIP is available at $10 \mathrm{~m}$, whereas the concentrations of gases are measured at $1.5 \mathrm{~m}$. A logarithmic decrease of the wind forcing from 10 to $1.5 \mathrm{~m}$, depending on the rugosity, has been applied, to calculate deposition velocities at $1.5 \mathrm{~m}$.

We have therefore calculated monthly means (from 3hourly values) of deposition velocities for $\mathrm{NO}_{2}, \mathrm{HNO}_{3}$ and $\mathrm{NH}_{3}$, in order to reproduce the seasonal cycle of the deposition process. The monthly means deposition velocities range from 0.1 to $0.33 \mathrm{~cm} / \mathrm{s}$ for $\mathrm{NO}_{2}$, from 0.34 to $0.61 \mathrm{~cm} / \mathrm{s}$ for $\mathrm{HNO}_{3}$ and from 0.11 to $0.39 \mathrm{~cm} / \mathrm{s}$ for $\mathrm{NH}_{3}$, where the higher values are found during the wet season. These values are in the lower range of usual deposition velocities found in the literature.The underestimation is larger for $\mathrm{HNO}_{3}$ and $\mathrm{NH}_{3}$ than for $\mathrm{NO}_{2}$, for the same meteorological forcing. This is due to the fact that wind speed is low in the forcing $(2.5,2.4$ and $1.9 \mathrm{~m} / \mathrm{s}$ as a yearly average in Agoufou, Banizoumbou and Katibougou respectively). Low wind speed involves high aerodynamic resistance $(\mathrm{Ra})$. Large $\mathrm{Ra}$ will have a strong influence on $\mathrm{HNO}_{3}$ deposition velocity, because canopy resistance for this specie is negligible, a lower influence for $\mathrm{NH}_{3}$ and a small influence for $\mathrm{NO}_{2}$. These processes have been comprehensively described in Hanson and Lindberg (1991), giving different deposition velocities depending on the wind speed at a same site, Duyzer and Fowler (1994), and more recently, Zhang et al. (2009). The main uncertainty of the deposition velocities is linked to the wind forcing, and to the type of soil represented in the model. The type of soil is not considered directly in this calculation, but indirectly via the roughness length. The difference between the wind in the forcing and the wind measured in situ is between 5 and $35 \%$ depending on the site. A mean rate of $20 \%$ is applied for the wind speed uncertainty, leading to an uncertainty rate of $15 \%$ for $\mathrm{NH}_{3}, 13 \%$ for $\mathrm{NO}_{2}$ and $19 \%$ for $\mathrm{HNO}_{3}$ deposition velocities.

The authors are however aware that the inferential method is not the best one to evaluate $\mathrm{NO}_{2}$ and $\mathrm{NH}_{3}$ fluxes. Exchange of $\mathrm{NH}_{3}$ appears to behave as if a compensation point exists: $\mathrm{NH}_{3}$ is both emitted and deposited. The direction of the net flux will depend on the strength of the volatilization process and environmental conditions. The $\mathrm{NH}_{3}$ compensa- tion point has been widely studied for temperate climate vegetation (Sutton et al. (2007) and references therein), Trebs et al. (2006) have also described a detailed $\mathrm{N}$ budget in a tropical pasture site in Brazil, but the lack of micrometeorological data in the Sahel prevents from parameterizing and estimating, for example, stomatal emissions, cuticular desorption emissions, cuticular recapture of stomatal emissions (Sutton et al., 1998), key points for the compensation point concept. As a consequence, the emission and deposition fluxes of $\mathrm{NH}_{3}$ are estimated individually in this study. Concerning $\mathrm{NO}_{2}$ fluxes, chemical reactions leading to the rapid production or consumption of $\mathrm{NO}_{2}$ (ozone photochemistry) may induce errors in the calculation of dry deposition fluxes of $\mathrm{NO}_{2}$. A lot of studies have stated the limits of the inferential method for $\mathrm{NO}_{2}$ fluxes (as examples, Kramm et al., 1995, De Arellano and Duynkerke, 1992, Kristensen et al., 2010), and use detailed micrometeorological measurements and parameterizations to calculate the fluxes. According to De Arellano and Duynkerke (1992), if turbulence is parameterized in terms of an exchange coefficient, the chemical reactions may induce a 35\% difference between inert and reactive exchange coefficients. As a consequence, an additional uncertainty rate of $35 \%$ is added to the $\mathrm{NO}_{2}$ flux.

In this study, concentrations are measured with passive samplers (indirect method), and are integrated monthly. Although preferable, no micrometeorological measurements are available, because not affordable or not practical in such remote regions. While highly uncertain, the $\mathrm{NO}_{2}$ flux is estimated with the inferential method (which gives an idea of its contribution in the $\mathrm{N}$ budget), keeping in mind that it has to be validated with micrometeorological measurements in future field campaigns. As we use monthly means for concentrations and deposition velocities, the covariance between the two may induce an additional uncertainty (the missing covariance term), especially for species having strong diurnal variations, like $\mathrm{NO}_{2}$ (Matt and Meyers, 1993). This missing covariance term is reduced for species like $\mathrm{NH}_{3}$ and $\mathrm{HNO}_{3}$. A missing covariance uncertainty rate of $20 \%$ has been applied for $\mathrm{NO}_{2}$, and $10 \%$ for $\mathrm{NH}_{3}$ and $\mathrm{HNO}_{3}$.

Particulate $\mathrm{N}$ dry deposition $\left(\mathrm{NHH}_{4}^{+}\right.$and $\left.\mathrm{pNO}_{3}^{-}\right)$is not taken into account in this budget. Particle concentrations have been measured in Banizoumbou and Katibougou, and are very low: $p \mathrm{NH}_{4}^{+}=0.31 \pm 0.02 \mathrm{ppb}$ and $\quad p \mathrm{NO}_{3}^{-}=0.16 \pm 0.03 \mathrm{ppb}$ in Banizoumbou, $p \mathrm{NH}_{4}^{+}=0.17 \pm 0.06 \mathrm{ppb} \quad$ and $\quad p \mathrm{NO}_{3}^{-}=0.23 \pm 0.06 \mathrm{ppb}$ in Katibougou. The comparison of these concentrations with $\mathrm{NH}_{3}$ concentrations in both sites (2.9 to $10.4 \mathrm{ppb}$ in Banizoumbou, 1.8 to $6.9 \mathrm{ppb}$ in Katibougou, and 3.5 to $10.5 \mathrm{ppb}$ in Agoufou) leads to the conclusion that particulate deposition is negligible. As far as the authors know, no other particulate dry deposition measurements have been made in the remote regions of Sahel.

The total uncertainty applied to the fluxes is linked to the concentration measurements, the deposition velocity, the 
missing covariance (plus a term of flux divergence for $\mathrm{NO}_{2}$ ). The total rate of uncertainty applied for deposition fluxes is $70 \%$ for $\mathrm{NO}_{2}, 31 \%$ for $\mathrm{NH}_{3}$ and $38 \%$ for $\mathrm{HNO}_{3}$.

\subsubsection{Wet deposition}

An automatic precipitation collector specially designed for the IDAF network has been installed at all stations. A local operator collects water from each rainfall event in a Greiner tube $(50 \mathrm{ml})$. Preserving the rainwater samples from contamination is an important issue since microbial input could modify its chemical composition. Samples are refrigerated at $4^{\circ} \mathrm{C}$ and preserved with $15 \mathrm{mg}$ of thymol biocide or stored in a deep freeze environment. Ion Chromatography (IC) procedures are given in Galy-Lacaux and Modi (1998). The uncertainty of annual and monthly rainfall depth measured with standard rain gauges is about $10 \%$. Precipitation coverage length (PCL\%) is about $100 \%$ for the studied sites in 2006. The percent Total Precipitation (TP\%) that represents the completeness of precipitation depth associated with valid chemical analysis is around $80-100 \%$ for all the sites. Chemical composition of rain is determined using Ionic Chromatography. The laboratory of Aerologie participate since 1996 to the international intercomparison program organized annually by WMO (World Meteorological Organization, 1997). According to prior results and through intercomparison tests organized by WMO, analytical precision is estimated to be $5 \%$ or better for all ions, within the uncertainties on all measured values presented here. The concentrations are given in $\mu \mathrm{eqL} \mathrm{L}^{-1}$ and we assume that the first digit after the comma is significant. Combining all the uncertainties of measurements and calculations, the uncertainty of the wet deposition fluxes is estimated to be about $10 \%$.

To calculate wet nitrogen deposition in African dry savannas for the year 2006, we have compiled the annual Volume Weighed Mean (VWM) concentrations of nitrate and ammonium from the precipitation collected at the 3 IDAF stations. The computation of nitrate and ammonium wet deposition has been done according to the 2006 annual rainfall for the studied sites. The rainfall depths registered at Banizoumbou (Niger), Katibougou and Agoufou (Mali) are $505.2 \mathrm{~mm}, 588.2 \mathrm{~mm}$ and $374 \mathrm{~mm}$ respectively. Nitrate and ammonium concentrations at the dry savannas sites are in the upper range of all the African ecosystems, with values from 37 (in Banizoumbou) to 31 (in Katibougou) $\mu \mathrm{eqL} \mathrm{L}^{-1}$ of $\mathrm{NH}_{4}^{+}$ and a range of 7 (Banizoumbou) to 16 (Katibougou) $\mu \mathrm{eq}^{-1}$ of $\mathrm{NO}_{3}^{-}$(Sigha et al., 2003; Yoboué et al., 2005; Dentener et al., 2006).

In the Sahel region, the major source of precipitation nitrate content comes from natural $\mathrm{NO}_{\mathrm{x}}$ emissions from soils, whereas $\mathrm{NO}_{\mathrm{x}}$ production from lightning plays a minor role for wet deposition (Tost et al., 2007), and it is not taken into account in this budget. Nitrate concentration in precipitation represents the final result of homogeneous and heterogeneous processes of nitrogenous gases and particles in the atmosphere and cloud water. Nitric oxide (NO) is the major nitrogen compound released from savanna soils in the nonburning season (Serça et al., 1998), and a large fraction of NO produced is oxidized in the atmosphere through photochemical reactions, into $\mathrm{HNO}_{3}$ or organic nitrates. $\mathrm{HNO}_{3}$, which is extremely soluble in water, is thus easily scavenged by clouds. Galy-Lacaux et al. (2001) have demonstrated that heterogenous processes between nitric acid and mineral particles are present all over the African continent.

Ammonium content in precipitation results from inclusion of gaseous ammonia and particles containing $\mathrm{NH}_{4}^{+}$in precipitating clouds. The highest values of ammonium compounds in precipitation registered in the semi-arid regions have been attributed to strong sources of ammonia from domestic and pastoral animals during the wet season (Galy-Lacaux and Modi, 1998). The concentration of dissolved organic nitrogen $(\mathrm{DON})$ in rain is not measured within the IDAF network, and it remains rather difficult to quantify the part of DON in the total wet deposition budget. A study performed in North Carolina from Whitall et al. (2002) states that DON could represent a third of the total wet deposition budget, whereas Hill et al. (2005) found that DON represents $18 \%$ of the wet deposition in an open field in Michigan. The budget presented in this study is therefore underestimated, in a proportion that is difficult to asses, but could represent $20 \%$ of the wet deposition.

\subsection{Emission}

\subsubsection{NO biogenic emission from soils: model characteristics}

Biogenic emissions from soils are derived from an Artificial Neural Network (ANN) approach. The resulting algorithm provides on line biogenic NO emissions and is developed in Delon et al. (2007). It is fully coupled to the SVAT model ISBA, and has been previously tested in the 3-D coupled chemistry-dynamics model MesoNH-C (which uses surface scheme ISBA) to reproduce NO pulses after a rain event in Niger (Delon et al., 2008). NO emissions from soils in ISBA are obtained for the year 2006 at a spatial resolution of $0.5^{\circ}$ and a time resolution of $3 \mathrm{~h}$. In the following sections, NO fluxes are averaged on a $3^{\circ} / 3^{\circ}$, window around each specific station. The simulated domain extends from $5^{\circ} \mathrm{S}$ to $20^{\circ} \mathrm{N}$ in latitude, and from $20^{\circ} \mathrm{W}$ to $30^{\circ} \mathrm{E}$ in longitude, but only the Sahel region $\left(15^{\circ} \mathrm{W}: 10^{\circ} \mathrm{E}, 12^{\circ} \mathrm{N}: 18^{\circ} \mathrm{N}\right)$ will be explored in this study. The meteorological forcing, developed within ALMIP, is obtained from a data set based on the merging of ECMWF (European Centre of Medium Range Weather Forecast) atmospheric state variables, and TRMM-3B42 3-hourly data for the precipitation. LAND-SAF data is used for downwelling longwave and shortwave radiative fluxes (Geiger et al., 2008; Huffman et al., 2007). A more comprehensive description of ALMIP may be found in Boone et al. (2009). 
The NO flux from soil is a non linear function of seven soil surface parameters: surface WFPS, surface and deep soil temperatures, $\mathrm{pH}$, sand percentage, fertilisation rate and wind speed. Surface WFPS is deduced from the simulated soil surface moisture. Surface and deep soil temperatures are also calculated by the model. Wind speed is provided by the atmospheric forcing. The $\mathrm{pH}$ map is obtained from IGBPDIS (1998, http://www.sage.wisc.edu/atlas) soil data base, at a spatial resolution of $0.5^{\circ} / 0.5^{\circ}$. Sand percentage is obtained from the ECOCLIMAP data base (Masson et al., 2003), at a resolution of $1 \mathrm{~km} / 1 \mathrm{~km}$. We assume that the most important driving parameters for our study are surface soil temperature and WFPS (calculated from soil moisture). Therefore, the uncertainty of the biogenic NO flux is calculated from the derived of the non linear function regarding soil surface temperature and moisture in ISBA (we approximate that the flux fluctuation in our study is mainly due to the fluctuation of these two parameters). The uncertainty of the NO flux from soil is calculated month by month and site by site. It ranges from 3 to $45 \%$ (18\% in annual mean) in Agoufou, from 5 to $68 \%$ (25\% in annual mean) in Banizoumbou, and from 8 to $56 \%$ (20\% in annual mean) in Katibougou, depending on the month.

The fertilization rate provided to the model is based on the calculation of $\mathrm{N}$ released by organic fertilization (i.e. cattle dung), for each country. Indeed, data bases of land use do not provide enough information in the Sahel concerning synthetic fertilization. Galloway et al. (2004) give an estimate of $2.5 \mathrm{TgNyr}^{-1}$ for the $\mathrm{N}$ input by fertilization production for the whole African continent, and Bouwman et al. (1997) show no emission from synthetic fertilizer use in the Sahelian band $\left(12-18^{\circ} \mathrm{N}\right)$. Schlecht and Hiernaux (2004) state that manure from livestock is an important source of organic matter and nutrients due to limited access to mineral fertilizers. These low assessments corroborate the assumption that the use of synthetic fertilizers in the Sahel is not a common feature, and can be neglected in our inventory.

Therefore, significant work was done to develop our own data base for organic fertilization for 23 countries of West and Central Africa which are contained in our simulation domain. These countries are, in alphabetical order: Benin, Burkina Faso, Cameroon, Chad, Congo, Democratic Republic of Congo, Equatorial Guinea, Gabon, Gambia, Ghana, Guinea Bissau, Guinea, Ivory Coast, Liberia, Mali, Mauritania, Niger, Nigeria, Republic of Centre Africa, Senegal, Sierra Leone, Sudan, and Togo.

The $\mathrm{N}$ quantity released by livestock is calculated from Schlecht et al. (1998), in gNhead ${ }^{-1}$ day $^{-1}$, for cows, sheep and goats. This estimate is multiplied by the number of animals per $\mathrm{km}^{2}$ in each country. The animal population is obtained in each region of each country from the FAO (Food and Agriculture Organization) Global Livestock Production and Health Atlas GLiPHA (2009, http://kids.fao.org/glipha/). The resulting inventory of $\mathrm{N}$ is introduced in the ANN algorithm as $\mathrm{N}$ input in $\mathrm{kgNha}^{-1} \mathrm{~h}^{-1}$. The data needed to build this inventory are, however, a source of uncertainty: the $\mathrm{N}$ input calculated from Schlecht et al. (1998), which gives $45 \mathrm{kgNanimal}^{-1} \mathrm{yr}^{-1}$ in a small region of Niger, remains low when generalized to the West African region. Indeed, Mosier et al. (1998) gives an estimate of $170 \mathrm{kgNanimal}^{-1} \mathrm{yr}^{-1}$ for the whole African continent, and Bouwman and Van Der Hoek (1997) gives an estimate of $130 \mathrm{kgNanimal}^{-1} \mathrm{yr}^{-1}$ in developing countries. These differences may be explained first because poultry, camels and donkey excreta are not taken into account in Schlecht et al. (1998) study, and second because this study is limited to a small region in Niger where the acidic sandy soils, which are predominant in the region, are inherently poor in $\mathrm{N}$ (Schlecht et al., 2004). Compared to the West African region, they do not provide a representative uptake of $\mathrm{N}$ in food for grazing. Therefore, we have taken an intermediate value of $70 \mathrm{kgNanimal}^{-1} \mathrm{yr}^{-1}$ for cows and $20 \mathrm{kgNanimal}^{-1} \mathrm{yr}^{-1}$ for sheep and goats for our study domain, which yields a total $\mathrm{N}$ input of $23 \mathrm{kgNha}^{-1} \mathrm{yr}^{-1}$ in Agoufou (Mali), $25 \mathrm{kgNha}^{-1} \mathrm{yr}^{-1}$ in Banizoumbou (Niger) and $11 \mathrm{kgNha}^{-1} \mathrm{yr}^{-1}$ in Katibougou (Mali).

30 to $50 \%$ this $\mathrm{N}$ input will be used for the calculation of $\mathrm{NH}_{3}$ volatilization, the rest is used as input for the calculation of NO biogenic emissions by the ANN algorithm in the ISBA surface model (the justification for this distribution is explained below, Sect. 2.2.2). The uncertainty concerning this part of the budget is one of the most difficult to calculate. It is linked to the animal population from GliPHa, certainly the more recent estimate available. Bouwman et al. (1997) have stated in their global inventory that the overall uncertainty caused by the animal population is probably inferior to $10 \%$. The same rate is applied in our inventory. The uncertainty depends also on the $\mathrm{N}$ release by livestock. The overall uncertainty for this source is estimated to be $50 \%$ from the same author. As a consequence, the uncertainty applied on $\mathrm{NH}_{3}$ volatilization is $51 \%$ in our study.

Figure 1 shows the NO biogenic flux from soils in the simulation domain in terms of the annual mean in Fig. 1a and JJAS mean (June July August September) in Fig. 1b. Indeed, JJAS corresponds to the wet season in West Africa, when the monsoon flux (cool and wet air coming from the ocean) reaches its northernmost position bringing humid air and intense precipitation in the Sahel. As mentioned in Yienger and Levy (1995), Jaeglé et al. (2004), Butterbach-Bahl et al. (2004) and references cited therein, NO emission is principally driven by soil moisture in tropical regions, and the most intense emissions occur in the Sahel when the first rains fall on the very dry soils. As shown in Fig. 1b, soil emissions in the Sahel reach their strongest values during the rainy season from June to September. In this study, we will only focus on the Sahelian region $\left(12^{\circ} \mathrm{N}: 18^{\circ} \mathrm{N}, 15^{\circ} \mathrm{W}: 10^{\circ} \mathrm{E}\right)$ and the magnitude of fluxes in wet savanna or forests areas or other tropical ecosystems will not be discussed here. 


\subsection{2 $\mathrm{NH}_{3}$ emission by volatilization}

Ammonia is formed in soils from biological degradation of organic compounds and ammonium, as represented by the equation 1 :

$\mathrm{NH}_{4}^{+}(a q) \rightarrow \mathrm{NH}_{3}(a q) \rightarrow \mathrm{NH}_{3}(g) \rightarrow \mathrm{NH}_{3}($ atm $)$

Where $(a q)$ stands for aqueous, $(g)$ for gaseous and (atm) for atmospheric loss. $\mathrm{NH}_{4}^{+}(a q)$ depends on soil cation exchange reactions, soil moisture content and net mineralization. The concentration of $\mathrm{NH}_{3}(\mathrm{aq})$ depends on ammoniacal $\mathrm{N}$, temperature and $\mathrm{pH}$. The rate of gas dispersion in the natural environment depends on the temperature gradient, and wind speed (Vlek, 1981). After $\mathrm{NH}_{3}$ is emitted to the atmosphere, each nitrogen atom can participate in a sequence of effects, known as the nitrogen cascade in which a molecule of $\mathrm{NH}_{3}$ can, in sequence, impact atmospheric visibility, soil acidity, forest productivity, terrestrial ecosystem biodiversity, stream acidity, coastal productivity (Galloway and Cowling, 2002), soil acidification and eutrophication (Bouwman and Van Der Hoek, 1997).

The current annual $\mathrm{NH}_{3}$ emission in developing countries of $15 \mathrm{TgN}$ accounts for $2 / 3$ of the global emissions from animal excreta. The fraction of the $\mathrm{N}$ excretion that is lost as $\mathrm{NH}_{3}$ ranges from 10 to $36 \%$, depending on animal-waste management and animal category (Bouwman and Van Der Hoek, 1997; Bouwman et al., 1997). More recently, Bouwman et al. (2002a) stated that 25, 28 and $33 \%$ of $\mathrm{N}$ use in Western Africa is released as $\mathrm{NH}_{3}$ in intensive grasslands, upland crops and wetland rice, respectively. The difficulty of obtaining reliable data concerning the use of animal manure, and management practices in tropical countries leads to uncertainties in estimating the $\mathrm{NH}_{3}$ loss, particularly in semiarid regions like the Sahel. However, one can suppose that better conditions are encountered in the Sahel region which favours $\mathrm{NH}_{3}$ volatilization, such as high temperatures, low soil moisture and bare soil surfaces. As a consequence, two different loss rates (30 and 50\%) have been applied to the input of $\mathrm{N}$ by animal manure previously prescribed for the calculation of $\mathrm{NO}$ emissions. This leads to a $\mathrm{N}-\mathrm{NH}_{3}$ volatilization estimated between $7.2 \pm 3.7$ and $12.4 \pm 6.3 \mathrm{kgNha}^{-1} \mathrm{yr}^{-1}$ in Agoufou, $8.1 \pm 4.2$ and $12.8 \pm 6.6 \mathrm{kgNha}^{-1} \mathrm{yr}^{-1}$ in Banizoumbou, and between $3.9 \pm 2$ and $6.2 \pm 3.2 \mathrm{kgNha}^{-1} \mathrm{yr}^{-1}$ in Katibougou, reported in Table 2. Bouwman et al. (1997) estimate the emission from domesticated animals in the Sahelian band between 0.5 and $5 \mathrm{kgNha}^{-1} \mathrm{yr}^{-1}$ for the year 1990 .

\subsection{3 $\mathrm{NO}_{\mathrm{x}}$ and $\mathrm{NH}_{3}$ emission from biomass burning}

Global biomass burning inventories for gases and particles are available from January 2005 to December 2006 on the Laboratoire d'Aérologie website (http://www.aero.obs-mip. fr:8001/). The available spatial resolution is $1 \mathrm{~km}-1 \mathrm{~km}$, and the time scale is daily. These global inventories use the L3JRC burnt area product (Liousse et al., 2010) based on the SPOT-VGT vegetation satellite and Global Land Cover (GLC) vegetation map, together with data on biomass densities and burning efficiencies. Such data, which were not available for the GLC2000 vegetation types but for the UMD (Hansen et al., 2000) global land cover product (Michel et al., 2005) have been established from correspondences between the 13 UMD vegetation classes and GLC2000 vegetation classes (Liousse et al. (2010), Mieville et al. (2010)). Emission factors for gaseous species were chosen following Andreae and Merlet (2001). In the present study, we used the inventories for $\mathrm{NO}, \mathrm{NO}_{2}$ and $\mathrm{NH}_{3}$ species in the region of interest ( -5 to $20^{\circ} \mathrm{N},-20$ to $30^{\circ} \mathrm{E}$ ). Monthly means and averages in a $5^{\circ} / 5^{\circ}$ window around each specific station (to ensure a sufficient sampling of fire events) are used to evaluate the potential impact of biomass fires at the local/regional scale.

The following relative uncertainties are applied: $20 \%$ for burned areas (Tansey et al., 2008), 30\% for the biomass density, 25\% for the burning efficiency (Stroppiana et al. (2009), Jain et al. (2007)), 31\% for the emission factor (Andreae and Merlet, 2001). The total uncertainty for both $\mathrm{NH}_{3}$ and $\mathrm{NH}_{\mathrm{x}}$ fluxes is $54 \%$.

Long range transport of nitrogen emissions from remote fires over southern Africa are not considered here due to the northward position of the stations in dry savanna areas. Indeed, Mari et al. (2008) and Sauvage et al. (2007) have shown that the impact of fire emissions occurring in the southern hemisphere from June to September was limited to coastal regions in the gulf of Guinea, and did not influence sites to the north.

\subsection{4 $\mathrm{NO}_{\mathrm{x}}$ and $\mathrm{NH}_{3}$ emission from domestic fires}

Combustion of biofuel is mainly used for cooking in the Sahel. Biofuel use provides a constant emission all year long and is a potential source of trace gases. Ludwig et al. (2003) (and references therein) show that $0.5 \mathrm{TgNO} / \mathrm{yr}$ is emitted over the African continent due to biofuel consumption. In the present study, $\mathrm{NO}_{\mathrm{x}}$ and $\mathrm{NH}_{3}$ emission from domestic fires uses the methodology from Junker and Liousse (2008), for the most recent existing year (2003). Due to a lack of knowledge of the emission factor as a function of countries, fuels, activity, technology/norm combinations, this methodology is based on a lumping procedure to account main factors of vulnerability. Nine emission factors are defined for each fuel category, and 3 main activities are considered (traffic, domestic, industrial), with 3 levels of technology linked to each countryś development level (developed, semi-developed, developing). Reference $\mathrm{NO}_{\mathrm{x}}$ emission factors values were given by Andreae and Merlet (2001), and on the 2 following websites: http://www.naei.org.uk/reports.php, and http: //www.transport.govt.nz/.

$\mathrm{NH}_{3}$ emissions factors are also given in Andreae and Merlet (2001). Consumption data are given by the United Nations database. Annual emissions are calculated country by 
country, and then gridded at $25 \mathrm{~km} / 25 \mathrm{~km}$ resolution (Assamoi and Liousse, 2010). The monthly input of nitrogen compounds is therefore constant all year long, and is averaged over a $5^{\circ} / 5^{\circ}$ window around each specific station to consider the local/regional impact of these emissions.

Uncertainties are mainly linked to wood and charcoal consumption estimates (50\%, citetAssamoi09) and emission factors (31\% Andreae and Merlet (2001). The total uncertainty applied to domestic fires is $60 \%$ for both compounds.

\section{Results and discussion}

As mentioned in Sect. 2.1, deposition fluxes (dry + wet) are estimated from concentration measurements at the IDAF stations. All deposition fluxes are converted in $\mathrm{kgNha}^{-1} \mathrm{yr}^{-1}$ and compared to emission fluxes in the same unit. Oxidized and reduced $\mathrm{N}$ compounds will be first treated separately. Then, a total budget will be estimated at the annual scale.

\subsection{Monthly evolution of Nitrogen oxidized compounds}

Nitric oxide (NO) and nitrogen dioxide $\left(\mathrm{NO}_{2}\right)$ react rapidly in the atmosphere and are referred to jointly as $\mathrm{NO}_{\mathrm{x}}$. In turn, $\mathrm{NO}_{\mathrm{x}}$ can be incorporated into organic compounds such as peroxyacetyl nitrate (PAN) or alkyl nitrate, or further oxidized to $\mathrm{HNO}_{3}$. Gas-phase $\mathrm{HNO}_{3}$ can be converted to aerosol nitrate $\left(\mathrm{NO}_{3}^{-}\right)$(e.g., by reaction with ammonia). PAN can convert back into $\mathrm{NO}_{2}$, and in hot temperature conditions its lifetime is short (few hours), so concentrations may remain low despite abundant photochemical radicals that promote PAN formation (Munger et al., 1998). We can therefore reasonably consider that the emission of NO (both biogenic and anthropogenic) at the surface is the beginning of the formation of all other reactive oxidized nitrogen compounds in the atmosphere. Non reactive $\mathrm{N}$ compounds $\left(\mathrm{N}_{2}\right.$, $\mathrm{N}_{2} \mathrm{O}, \mathrm{N}_{2} \mathrm{O}_{5}$ ) are not included in the budget, because emission fluxes of these compounds in arid regions are negligible. According to Meixner and Yang (2004), $\mathrm{N}_{2} \mathrm{O}$ fluxes from semiarid soils are expected to be low, and those from arid soils are very low, due to the fact that $\mathrm{N}_{2} \mathrm{O}$ emission is favoured by denitrification processes at high soil moisture content. Galbally et al. (2008) (and references therein) suggest, however, that $5 \%$ of the global soil emissions of $\mathrm{N}_{2} \mathrm{O}$ from agricultural disturbances (i.e. land conversion to agriculture) may occur in semi arid and arid zones. This fraction is considered to be low, hence $\mathrm{N}_{2} \mathrm{O}$ emissions are not considered. Organic compounds such as PAN are also omitted from this budget, assuming that they are converted into $\mathrm{NO}_{2}$ and that their concentrations are negligible in non polluted areas (around $100 \mathrm{ppt}$; Seinfeld and Pandis, 1998), compared to statistical values of $\mathrm{NO}_{2}(2.5 \pm 0.6 \mathrm{ppb})$ and $\mathrm{HNO}_{3}(0.5 \pm 0.2 \mathrm{ppb})$ concentrations, based on a 10 year period (Adon et al., 2010). Hence, it has to be mentioned that the three $\mathrm{N}$ gases measured

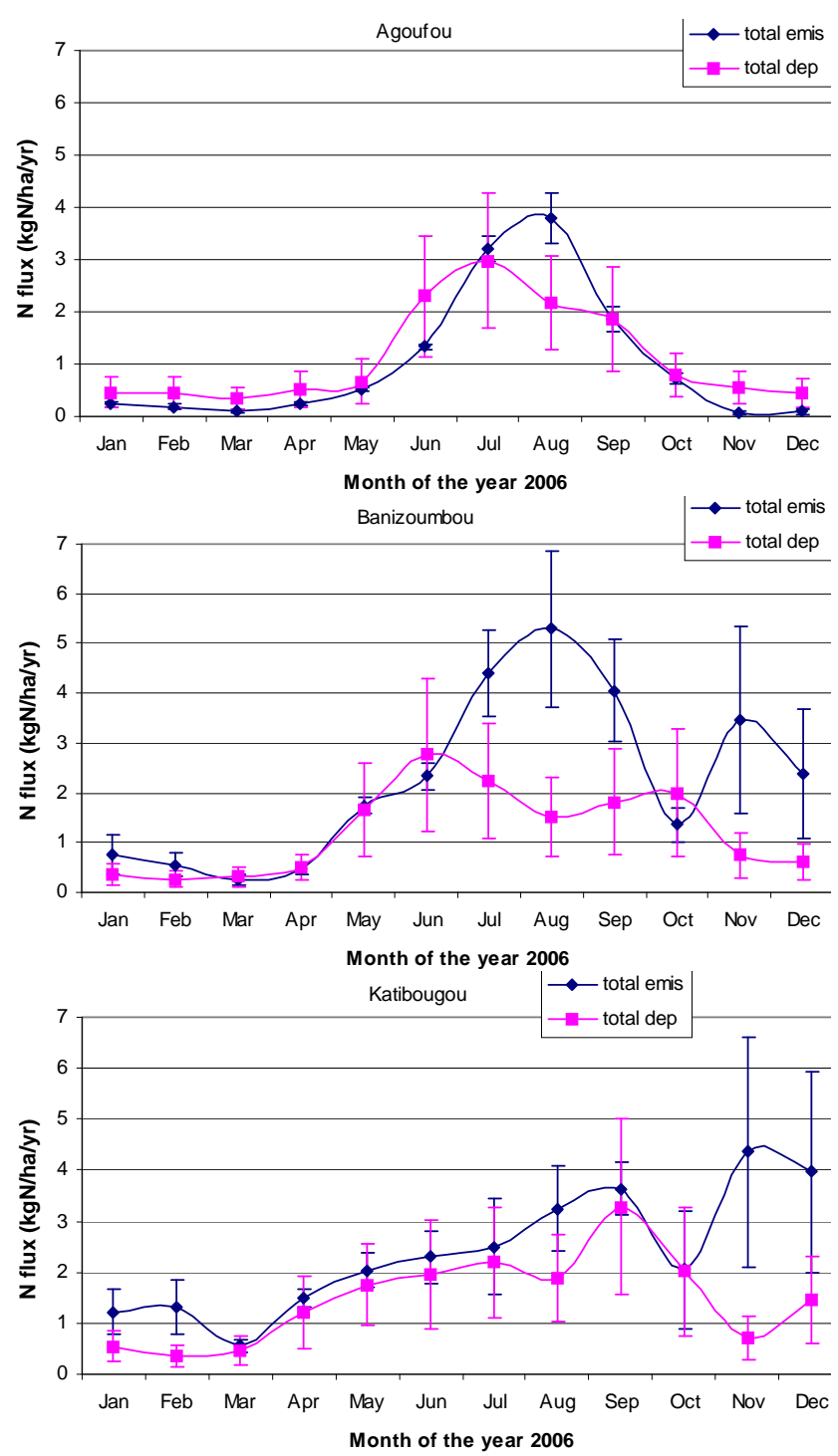

Fig. 2. Monthly evolution of fluxes and associated uncertainties: in purple, dry deposition of $\mathrm{NO}_{2}$ and $\mathrm{HNO}_{3}+$ wet deposition of $\mathrm{NO}_{3}$ and in blue, biogenic NO emission from soils + biomass burning flux + domestic fires flux in $\mathrm{kgNha}^{-1} \mathrm{yr}^{-1}$ for IDAF dry savanna stations.

and deposited (and thus considered in the budget) do not represent all the $\mathrm{N}$ gaseous compounds in the atmosphere.

As a consequence in this study, the total $\mathrm{NO}_{\mathrm{x}}$ emission flux is defined as the sum of biogenic NO soil emission flux + biomass burning $\mathrm{NO}_{\mathrm{x}}$ flux + domestic fire $\mathrm{NO}_{\mathrm{x}}$ flux. It is compared to deposition flux of oxidized components, defined as the sum of estimated dry deposition of $\mathrm{NO}_{2}+\mathrm{HNO}_{3}$ in the gas phase, $+\mathrm{NO}_{3}^{-}$wet deposition flux.

Figure 2 presents the monthly evolution of emission and deposition oxidized $\mathrm{N}$ fluxes in Agoufou, Banizoumbou and Katibougou. Mean fluxes for each station at each season 
Table 1. Seasonal and annual mean emission and deposition fluxes and uncertainties (in $\mathrm{kgNha}^{-1} \mathrm{yr}^{-1}$ ) of oxidized nitrogen compounds in dry savanna stations.

\begin{tabular}{ccccccc}
\hline Site & \multicolumn{2}{c}{ Wet season Ox N } & \multicolumn{2}{c}{ Dry season Ox N } & \multicolumn{2}{c}{ Annual mean Ox N } \\
\hline & Deposition & Emission & Deposition & Emission & Deposition & Emission \\
Agoufou & $2.4 \pm 1.1$ & $2.5 \pm 0.2$ & $0.5 \pm 0.3$ & $0.3 \pm 0.04$ & $1.5 \pm 0.6$ & $1.0 \pm 0.1$ \\
Banizoumbou & $3.4 \pm 1.2$ & $3.6 \pm 0.8$ & $0.7 \pm 0.4$ & $1.3 \pm 0.6$ & $2.7 \pm 0.8$ & $2.2 \pm 0.7$ \\
Katibougou & $3.3 \pm 1.2$ & $2.6 \pm 0.7$ & $0.8 \pm 0.5$ & $2.1 \pm 0.9$ & $2.7 \pm 0.9$ & $2.4 \pm 0.8$ \\
\hline
\end{tabular}

Table 2. Annual mean emission and deposition fluxes and uncertainties (in $\mathrm{kgNha}^{-1} \mathrm{yr}^{-1}$ ) of reduced nitrogen compounds for dry savanna stations.

\begin{tabular}{ccc}
\hline Site & Annual mean NHx \\
\hline & Deposition & Emission with 30\% and 50\% volatilization rate \\
Agoufou & $5.1 \pm 1.0$ & $7.2 \pm 3.7-12.4 \pm 6.3$ \\
Banizoumbou & $6.0 \pm 1.1$ & $8.1 \pm 4.2-12.8 \pm 6.6$ \\
Katibougou & $4.6 \pm 0.9$ & $3.9 \pm 2.0-6.2 \pm 3.2$ \\
\hline
\end{tabular}

are reported in Table 1. The wet season lasts from June to September in Agoufou, from May to September in Banizoumbou, and from May to October in Katibougou. The first maximum during the wet season corresponds to biogenic emissions. During the wet season, emission fluxes are larger than deposition fluxes in Banizoumbou and Agoufou, due to the large amount of biogenic NO emissions in July and August, associated to the maximum of rainfall. It seems that all the $\mathrm{N}$ emitted is not represented in the deposition measurements, which include only $3 \mathrm{~N}$ gaseous compounds and do not include Organic Nitrogen, as mentioned above. During the dry season, emission fluxes are close to deposition fluxes.

Significant deposition fluxes commence at the beginning of the wet season (usually around May in dry savanna areas) due to a pulse emission flux which is produced over very dry soils when the first rains fall (Johansson et al. (1988), Yienger and Levy (1995), Otter et al. (1999), Yan et al. (2005), Delon et al. (2008). Adon et al. (2010) showed that the surface $\mathrm{NO}_{2}$ concentration has its first maximum at the beginning of the rainy season. Figure 2 shows that emission and deposition fluxes increase simultaneously, but note that the deposition maximum is early compared to the emissions. In the model, the biogenic NO emission is highly correlated with rainfall (i.e. the soil has become wet enough to produce sufficient emissions). Later in the season, the model keeps emitting, which is in contrast to site measurements which show a decrease in concentrations. Two factors may explain this: the emission module emits longer than it should, and sometimes rain events do not compare well between measurements and model (whereas the total annual measured rainfall is comparable with that deduced from the forcing). The latter results because it is difficult to compare point rainfall measurements to a satellite-based product at a 0.5 degree spatial scale, espe- cially because of the mostly convective nature of the rainfall in this region (e.g. Ali et al., 2003).

A second emission maximum is observed in november in Banizoumbou and Katibougou, and corresponds to fire occurence during the dry season, which imply an increase in $\mathrm{NO}_{\mathrm{x}}$ fluxes. The highest uncertainties represented on the emission flux are found in the dry season (November), when biomass burning emissions are important in Banizoumbou and Katibougou, and also in August, when soil moisture is high, as well as biogenic fluxes. Indeed, the biomass burning flux uncertainty is large, and the NO flux uncertainty is larger when soil moisture is larger. A second maximum in deposition is observed in September in Katibougou, and in October in Banizoumbou, shifted compared to the emission maximum, and less intense. The shift could be due to an overestimate of fire emissions compared to local deposition measurements. Furthermore, $\mathrm{HNO}_{3}$ deposition fluxes, superior to $\mathrm{NO}_{2}$ fluxes (because of higher deposition velocities), do not increase when fire emissions increase. Even if emission fluxes are larger than deposition fluxes, they keep similar orders of magnitude both in wet and dry seasons. Considering the high level of uncertainty of the $\mathrm{NO}_{2}$ flux, the maximum uncertainties in deposition fluxes are found when $\mathrm{NO}_{2}$ concentrations are large, i.e. during the wet season, and in september and october when fire emissions occur.

The comparison of these fluxes in Fig. 2 at the monthly scale shows a good agreement between emission and deposition magnitude, while underscoring the difficulties of analysing the nitrogen budget in such remote areas where too few measurements are available. Emission modelling presents an alternative to this lack of measurements, but many questions remain of concern, for example, the quantity of nitrogen contained in the soils, or the amount of emissions 

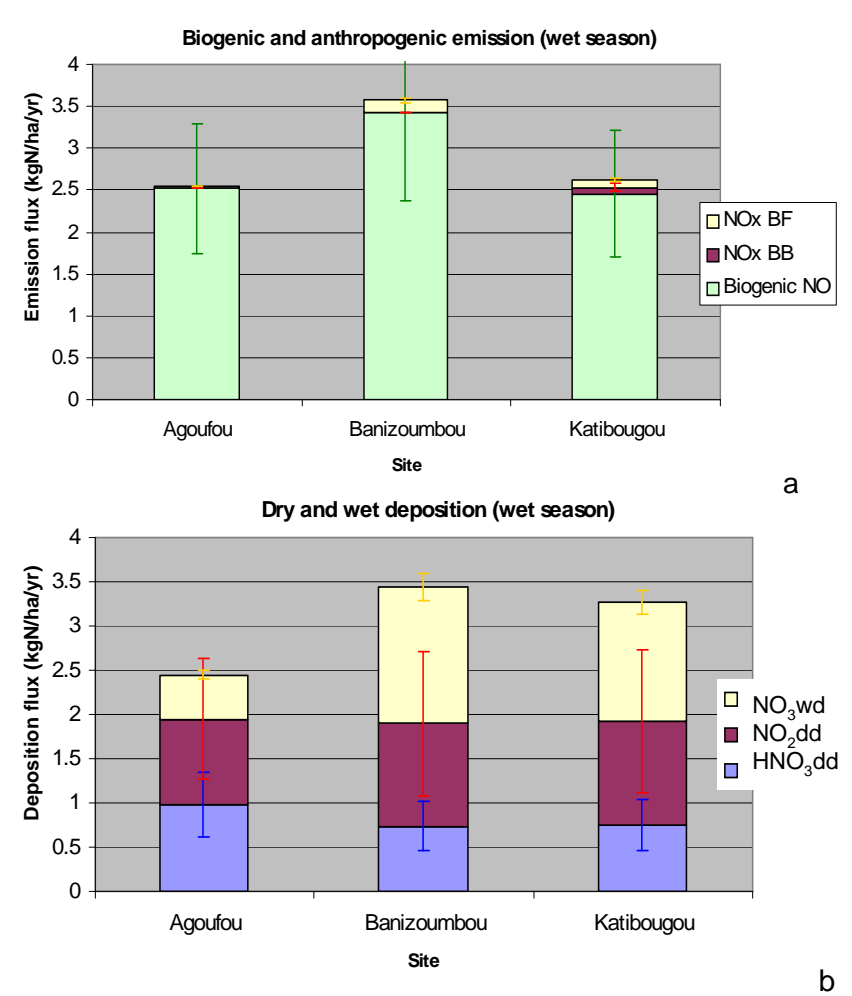

Fig. 3. Wet season emission (a) and deposition (b) fluxes, and associated uncertainties in $\mathrm{kgNha}^{-1} \mathrm{yr}^{-1}$ for oxidized nitrogen species at the three dry savanna stations. $\mathrm{BF}=$ biofuel, $\mathrm{BB}=$ biomass burning, wd=wet deposition, dd=dry deposition.

after the first rainfall in semi-arid regions. However, the joint exploitation of IDAF measurements and modelling results gives a unique opportunity to provide a nitrogen budget in Sahelian ecosystems. In the following, we will try to evaluate the contribution of biogenic and fire emissions to atmospheric deposition at the annual scale, both for oxidised and reduced nitrogen compounds.

\subsection{Annual and seasonal budget of $\mathrm{N}$ oxidised compounds}

Figure 3 shows the distribution of the $\mathrm{N}$ oxidized component emission fluxes (a) and deposition fluxes (b), for the wet season. The same repartition is given in Fig. 4a and b but for annual means in the three dry savanna stations. Uncertainty bars are given for each contribution in an approximated color.

It is obvious from these figures that the emission flux is dominated by the biogenic part, both in the wet season and for the annual mean. Mean values and uncertainties for each season are reported in Table 1. Emission fluxes at the annual scale range from $1.0 \pm 0.1$ to $2.4 \pm 0.8 \mathrm{kgNha}^{-1} \mathrm{yr}^{-1}$. These estimates are in the range of emission fluxes reported by Meixner and Yang (2004), which range from 0.02 to $34 \mathrm{kgNha}^{-1} \mathrm{yr}^{-1}$, in semi arid and arid ecosystems. In Bani-
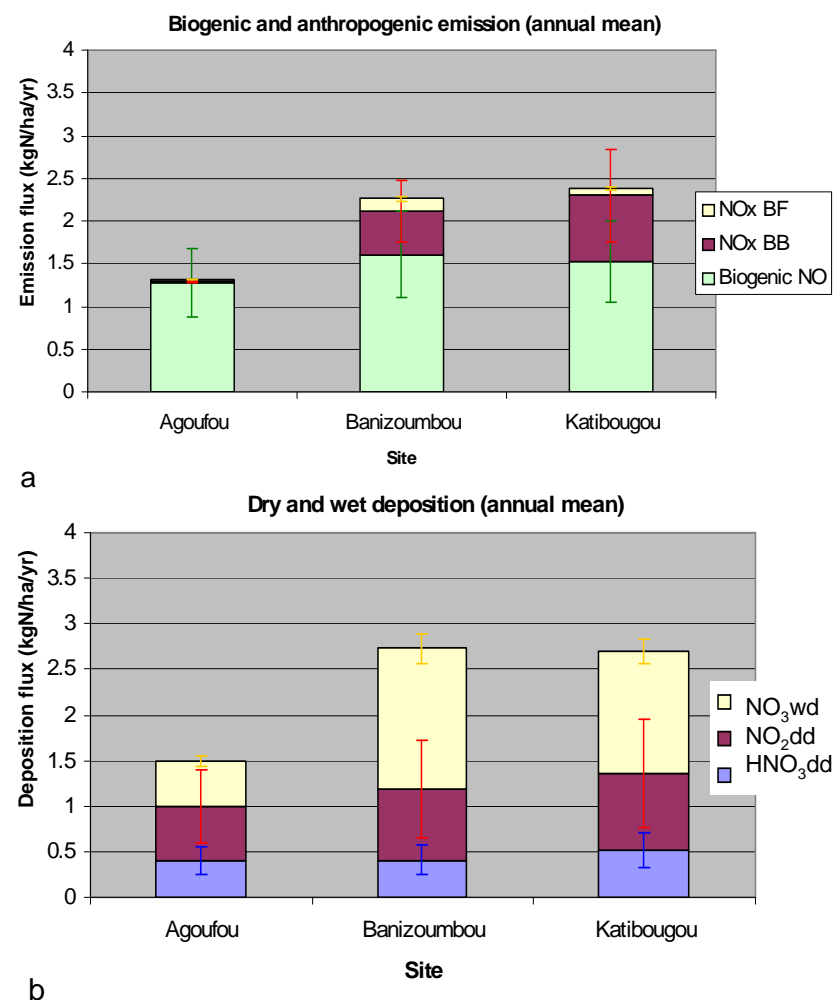

Fig. 4. Annual mean emission (a) and deposition (b) fluxes and associated uncertainties in $\mathrm{kgNha}^{-1} \mathrm{yr}^{-1}$ for oxidized nitrogen species at the three dry savanna stations. $\mathrm{BF}=$ biofuel, $\mathrm{BB}=$ biomass burning, wd=wet deposition, $\mathrm{dd}=$ dry deposition

zoumbou, measured emission fluxes up to $1.8 \mathrm{kgNha}^{-1} \mathrm{yr}^{-1}$ have been reported by Le Roux et al. (1995) and Serça et al. (1998).

In Figs. $3 b$ and $4 b$, the estimated dry deposition appears to be half of the total deposition, except in Agoufou, with the remaining half being wet deposition. This has already been observed in dry savanna stations and other IDAF stations in West African wet savanna (Galy-Lacaux et al., 2003). Of course, the high level of uncertainty of the dry deposition flux of $\mathrm{NO}_{2}$ could drastically change this repartition, in one direction or the other.

Large deposition fluxes are observed in Katibougou and Banizoumbou because of high wet deposition of $\mathrm{NO}_{3}^{-}$. Katibougou, which is the southernmost station, receives more rainfall than Banizoumbou and Agoufou, which could explain the high wet deposition flux. But in Banizoumbou, the strong deposition flux in the wet season can be explained by significant biogenic emissions at the beginning of this season, well reproduced by the model. Figures $3 \mathrm{a}$ and $4 \mathrm{a}$ show that no biomass burning contribution appears in Agoufou, due to the small quantity of biomass available during the dry season. $\mathrm{NO}_{2}$ concentration measurements do not show any increase in Agoufou in that season (Adon et al., 2010). The 

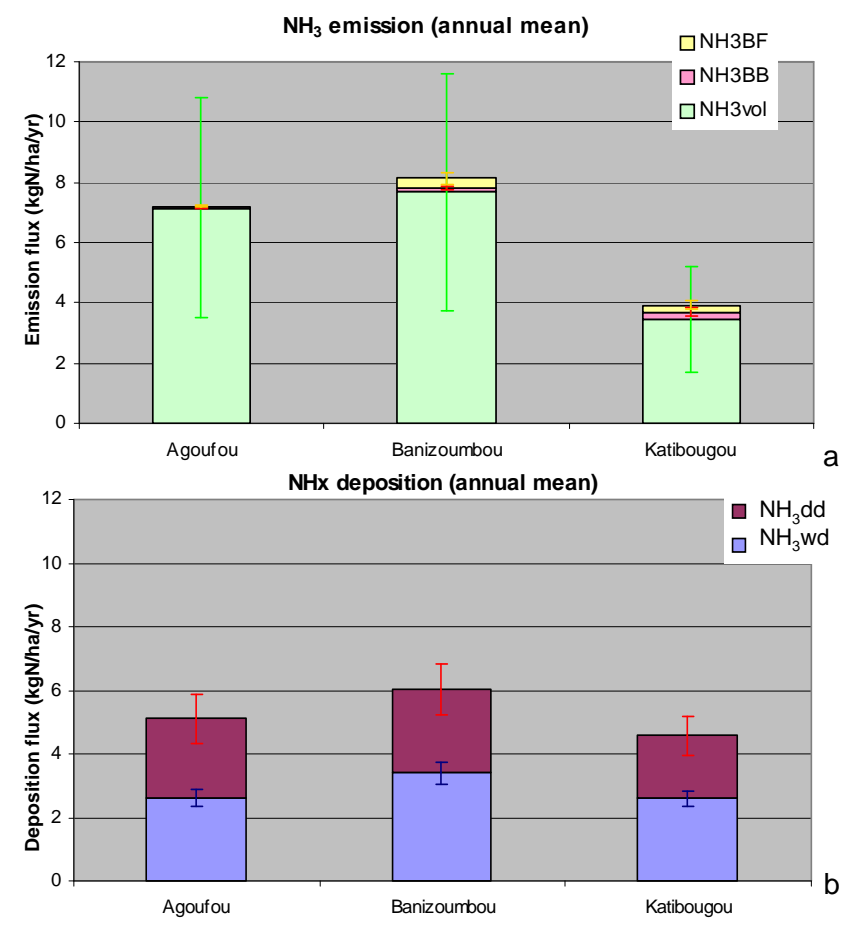

Fig. 5. Annual mean emission (a) and deposition (b) fluxes and associated uncertainties in $\mathrm{kgNha}^{-1} \mathrm{yr}^{-1}$ for reduced $\mathrm{N}$ compounds $\left(\mathrm{NH}_{3}\right.$ and $\left.\mathrm{NH}_{4}^{+}\right)$at the three dry savanna stations. $\mathrm{BF}=$ biofuel, $\mathrm{BB}=$ biomass burning, $\mathrm{wd}=$ wet deposition, $\mathrm{dd}=\mathrm{dry}$ deposition, vol=volatilization.

quantity of $\mathrm{N}$ available in the soil is not part of the systematic measurements in IDAF stations, but measurements in the Gourma region (Diallo and Gjessing, 1999) do not reflect any strong reservoir of $\mathrm{N}$. The release of nitrogen compounds in Agoufou and Banizoumbou specifically (because of the reduced rainfall amount) seems to be very powerful. Preliminary explanation could lie in the $\mathrm{N}$ input from $\mathrm{N}$-fixing crusts of cyanobacteria and lichens (Barger et al., 2005), and $\mathrm{N}$-fixing plants and trees (e.g. Acacia). Meixner and Yang (2004) state that despite the fact that deserts have low plant productivity, inorganic nitrogen can accumulate in desert and semi-desert soils during long dry periods.

Generally speaking, the deposition fluxes of oxidised N compounds in dry savanna stations is the consequence of strong biogenic emission fluxes in the wet season. Indeed, the contribution of emissions from biomass burning at the annual scale is only $12 \%$ and $5 \%$ of the total oxidised N emission flux, respectively, in Banizoumbou and Katibougou, and the contribution of domestic fires is negligible. The contribution of traffic from large cities to dry deposition during the wet season is also neglected, as shown by very low particulate concentrations whatever the season.

\subsection{Annual and seasonal budget of reduced compounds}

The dry and wet deposition of $\mathrm{NH}_{3}$ and $\mathrm{NH}_{4}^{+}$will be referred to as $\mathrm{NH}_{\mathrm{x}}$ in the following.

The calculation of $\mathrm{NH}_{3}$ volatilisation has already been developed in Sect. 2.2.2. The subsequent $\mathrm{NH}_{3}$ volatilization flux (30 to 50\% of the $\mathrm{N}$ input) is reported in Table 2. The assumption that the release is constant during the year is obviously not exact because of seasonal variations in the absorption and release depending on soil humidity, wind speed, and food quality for cattle. Owing to the lack of measurements in remote Sahelian areas, the lack of statistical data on cattle repartition and nitrogen content leads to many assumptions, implying of course a high level of uncertainty in determining the exact quantity of $\mathrm{NH}_{\mathrm{x}}$ released. But the relative level of volatilization from excreta compared to other sources of $\mathrm{NH}_{3}$ is maintained, when compared to emissions at the global scale (Bouwman et al., 1997; Galloway and Cowling, 2002). Figure 5 shows the annual repartition of emission and deposition $\mathrm{NH}_{\mathrm{x}}$ fluxes and the associated uncertainties as error bars. Annual mean values for each station are given in Table 2. The average $\mathrm{NH}_{\mathrm{x}}$ emission flux ranges from $6.4 \pm 3.3$ to $10.5 \pm 5.4 \mathrm{kgNha}^{-1} \mathrm{yr}^{-1}$ and is dominated by the volatilization flux, despite the high uncertainty rate applied on it. The mean deposition flux (dominated by dry deposition processes) is $5.2 \pm 1.0 \mathrm{kgNha}^{-1} \mathrm{yr}^{-1}$. These values are of the same order as deposition fluxes calculated in a tropical pasture site in Brazil, giving a range of $\mathrm{NH}_{3}$ fluxes between 6 and $12 \mathrm{kgNha}^{-1} \mathrm{yr}^{-1}$ (Trebs et al., 2006).

\subsection{Annual budget of oxidized and reduced nitrogen compounds at each station, and scaled up to the regional scale}

Figures 6 and 7 show the total deposition and emission fluxes of oxidized and reduced nitrogen compounds at the annual scale for each station. Uncertainties are shown in parenthesis. These figures allow the synthesis between Sects. 3.2 and 3.3, and show that the maximum (wet and dry) deposition and emission fluxes are dominated by the $\mathrm{NH}_{3}$ contribution, with respectively $77 \%, 68 \%$ and $52 \%$ at Agoufou, Banizoumbou and Katibougou stations for deposition flux, and respectively 84\%, 79\% and 63\% at Agoufou, Banizoumbou and Katibougou for the emission (for a $30 \% \mathrm{NH}_{3}$ volatilization rate). Whelpdale et al. (1997) have estimated that the contribution of oxidized nitrogen to the total deposition was about $23 \%$ in arid savannas, which corroborates our results. The second most important emission flux is given by the biogenic NO from soils.

The contribution of $\mathrm{NO}_{2}$ dry deposition flux, which presents the highest uncertainty, is only $9 \%$ in Agoufou and Banizoumbou, and $12 \%$ in Katibougou. An important decrease or increase of this flux (in the range of its uncertainty) will not impact drastically the total budget. The budget could 
Table 3. Total emission and deposition fluxes and uncertainties (in $\mathrm{kgNha}^{-1} \mathrm{yr}^{-1}$ ) of reduced and oxidized nitrogen compounds in dry savanna.

\begin{tabular}{ccc}
\hline Site & \multicolumn{2}{c}{ Annual mean } \\
\hline & Total Deposition & Total Emission with $30 \%$ and $50 \% \mathrm{NH}_{3}$ volatilization rate \\
Agoufou & $6.6 \pm 1.6$ & $8.5 \pm 3.8-13.7 \pm 6.5$ \\
Banizoumbou & $8.8 \pm 2.0$ & $10.4 \pm 4.9-15.1 \pm 7.2$ \\
Katibougou & $7.3 \pm 1.8$ & $6.3 \pm 2.8-8.6 \pm 4.0$ \\
Average & $7.5 \pm 1.8$ & $8.4 \pm 3.8-12.5 \pm 5.9$ \\
\hline
\end{tabular}

be however highly impacted by the large $\mathrm{NH}_{3}$ emission uncertainty.

Table 3 summarizes the mean $\mathrm{N}$ emission and deposition fluxes at the annual scale for each station. From these 3 sites, the average deposition flux, attributed to dry savanna ecosystems in Sahel, is $7.5( \pm 1.8) \mathrm{kgNha}^{-1} \mathrm{yr}^{-1}$, and the average emission flux ranges from $8.5 \pm 3.8$ to $12.5 \pm 5.9 \mathrm{kgNha}^{-1} \mathrm{yr}^{-1}$. The \pm values given in parenthesis represent the mean uncertainties carried through the entire calculation. Averaging the flux values of the 3 sites is a rather simple method to scale up the $\mathrm{N}$ budget, but the lack of data and information around the sites prevented us from using a more elaborated method. The deposition fluxes calculated here are of the same order of magnitude as deposition fluxes in temperate rural site reported by Zhang et al. (2009), ranging from 4.3 to $11 \mathrm{kgNha}^{-1} \mathrm{yr}^{-1}$. Deposition fluxes values remain in the same order of magnitude from one station to another. Common characteristics (same climate regime, same type of emission sources and amplitude, same type of vegetation and soil characteristics) deduced from these 3 stations, can be attributed to dry savanna ecosystems, and may also be scaled up to the Sahelian region $\left(12^{\circ} \mathrm{N}: 18^{\circ} \mathrm{N}\right.$, $15^{\circ} \mathrm{W}: 10^{\circ} \mathrm{E}$, i.e. $2.4 \times 10^{6} \mathrm{~km}^{2}$ ). Emission characteristics also give common features from one site to another, despite the stronger contribution of $\mathrm{NH}_{3}$ volatilization in Agoufou, due to the very weak contribution of biomass burning and biofuel fires in this remote area.

According to Mayaux et al. (2003), Aubréville (1949), and White (1986), we can consider that dry savanna (i.e; open grassland and open grassland with sparse shrubs) is representative of the main Sahelian ecosystem. It is therefore possible from these fluxes estimates to give an $\mathrm{N}$ annual budget of dry savanna Sahelian ecosystems. However, during the wet season, the portion of Sahel between $12^{\circ} \mathrm{N}$ and $13^{\circ} \mathrm{N}$ is highly cultivated. This zone will not emit and deposit $\mathrm{N}-\mathrm{NH}_{3}$ the same way as non cultivated and pastoral zones. Therefore, the budget calculated here, without considering a cultivated zone during the wet season, has to be considered as a maximum value.

Figure 8 gives the mean repartition that should be observed in the Sahel concerning nitrogen compound emission and deposition fluxes. Total deposition has been estimated to range between 1.4 and $2.3 \mathrm{TgN} / \mathrm{yr}$ (with a mean value of $1.84 \pm 0.44,1.3 \pm 0.2 \mathrm{TgN} / \mathrm{yr}$ attributed to reduced compounds, $0.5 \pm 0.2 \mathrm{TgN} / \mathrm{yr}$ attributed to oxidized compounds). Depending on the $\mathrm{NH}_{3}$ volatilization rate, the emission has been estimated to be between 1.1 and $4.5 \mathrm{TgN} / \mathrm{yr}, 1.1$ being the lower flux estimated with the $30 \%$ volatilization rate, and 4.5 being the highest estimate for $50 \%$ volatilization rate (for a $30 \%$ volatilization rate, the estimated emission is $2.0 \pm 0.9$, $1.5 \pm 0.8 \mathrm{TgN} / \mathrm{yr}$ for reduced compounds and $0.5 \pm 0.1$ for oxidized compounds), for the Sahel region.

These values have to be compared to global emission and deposition estimates: global $\mathrm{NO}_{\mathrm{x}}$ emission has been estimated at 44 (30-73) TgN/yr (Galbally et al., 2008), and $\mathrm{NH}_{3}$ global emission in 1990 has been estimated at 54 (40-70) $\mathrm{TgN} / \mathrm{yr}$ (Bouwman et al., 1997). Galloway et al. (2008) give a $100 \mathrm{TgN} / \mathrm{yr}$ for $\mathrm{NH}_{3}+\mathrm{NO}_{\mathrm{x}}$ emission in 1995. Our mean estimate of $\mathrm{N}$ compound emissions for the Sahel reaches $2.0 \mathrm{TgN} / \mathrm{yr}$, which is around $2 \%$ of the estimate of global $\mathrm{NH}_{3}+\mathrm{NO}_{\mathrm{x}}$ emissions cited above, from only $0.48 \%$ of the global surface area. Furthermore, Bouwman et al. (1997) have estimated the contribution from animal excreta to $\mathrm{NH}_{3}$ emissions at $21.7 \mathrm{TgN} / \mathrm{yr}$ at the global scale, plus $5.9 \mathrm{TgN} / \mathrm{yr}$ due to biomass and biofuel combustion. Our estimate of $\mathrm{NH}_{3}$ emission from volatilization and combustion would give $84 \%$ of $2.0 \mathrm{TgN} / \mathrm{yr}=1.7 \mathrm{TgN} / \mathrm{yr}$ in the Sahelian region only. These mean estimates give a rough idea of the importance of the $\mathrm{N}$ budget in the Sahelian dry savannas. As stated by Davidson and Kingerlee (1997) and Meixner and Yang (2004), these ecosystems constitute a significant part in the emission of Nitrogen compounds, whereas our knowledge of these remote areas is limited by a lack of measurements and studies.

\section{Conclusions}

This study is a first and original attempt to estimate both deposition and emission fluxes of a set of nitrogen species in dry savanna ecosystems, using simulated and calculated inventories, and in situ measurements. Deposition fluxes of $\mathrm{HNO}_{3}, \mathrm{NH}_{3}$ and $\mathrm{NO}_{2}$ are calculated according to the inferential method with measured concentrations and simulated deposition velocities, at the monthly scale. Emission fluxes of biogenic NO from soils are simulated with a NN derived 

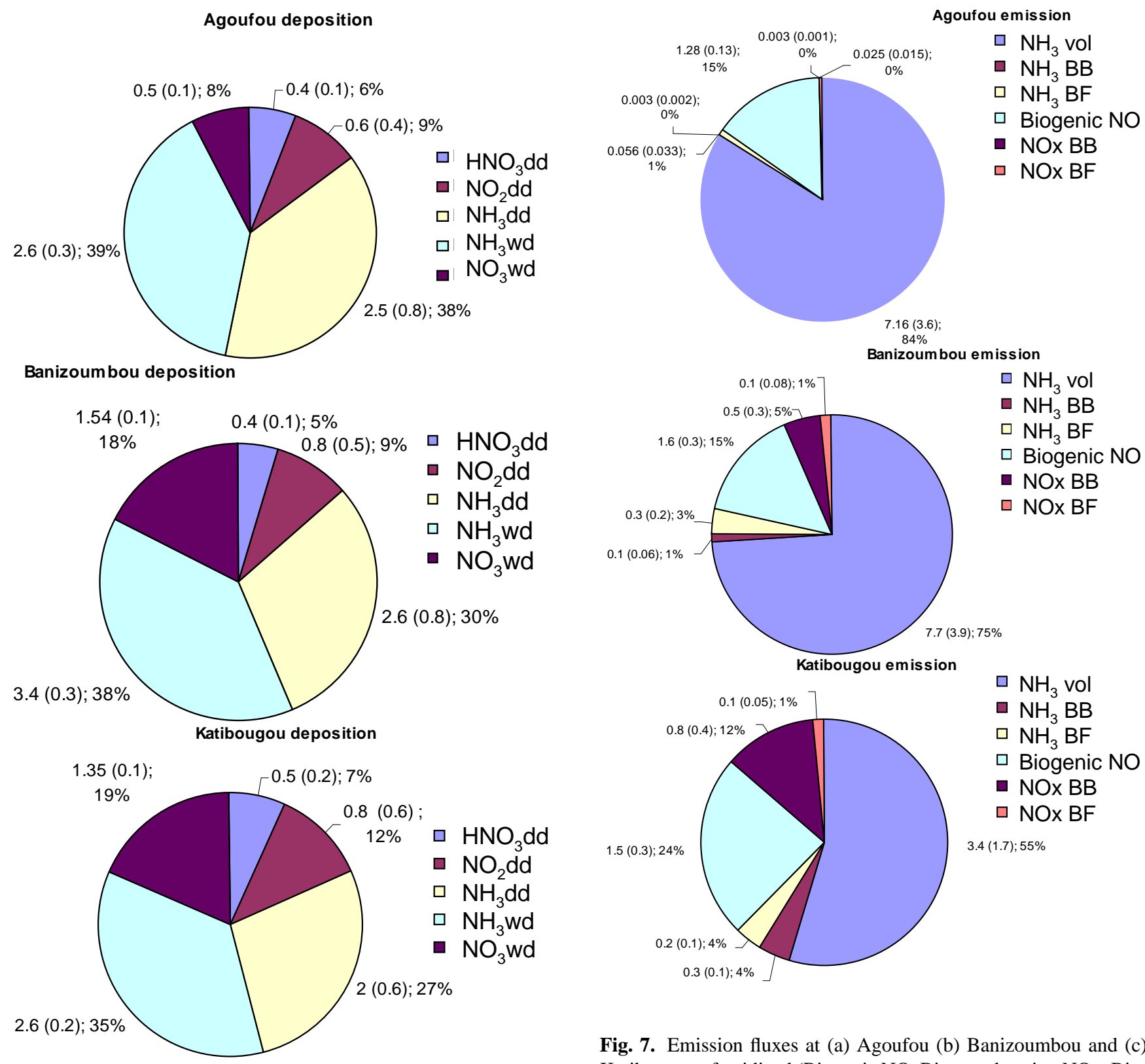

Fig. 7. Emission fluxes at (a) Agoufou (b) Banizoumbou and (c) Katibougou of oxidized (Biogenic NO, Biomass burning $\mathrm{NO}_{\mathrm{x}}$, Biofuel $\mathrm{NO}_{\mathrm{x}}$, ) and reduced (Biomass burning $\mathrm{NH}_{3}$, Biofuel $\mathrm{NH}_{3}$ and

Fig. 6. Dry and wet deposition fluxes at (a) Agoufou (b) Banizoumbou and (c) Katibougou of oxidized $\left(\mathrm{NO}_{2}, \mathrm{NO}_{3}^{-}, \mathrm{HNO}_{3}\right)$ and reduced $\left(\mathrm{NH}_{4}^{+}, \mathrm{NH}_{3}\right)$ nitrogen compounds. Annual mean, given as absolute value (relative uncertainty); contribution in \%

emission module coupled to a SVAT model, $\mathrm{NO}_{\mathrm{x}}$ and $\mathrm{NH}_{3}$ emission fluxes from biomass burning and domestic fires are calculated from satellite data.

In this study, we have first tried to reproduce the nitrogen oxidized compound emission and deposition evolution month by month at three different IDAF stations in dry savanna areas during 2006. The magnitude of deposition and emission fluxes is similar, but the maximum emission is later volatilized $\mathrm{NH}_{3}$ ) nitrogen compounds. Annual mean, given as absolute value (relative uncertainty); contribution in \%.

and larger than the maximum deposition during the rainy season. An annual budget of reduced and oxidized $\mathrm{N}$ emission and deposition fluxes has been calculated. It gives a mean estimate of $7.5( \pm 1.8) \mathrm{kgNha}^{-1} \mathrm{yr}^{-1}$ for total deposition, slightly dominated by wet deposition (53\% of the total), and $8.4( \pm 3.8) \mathrm{kgNha}^{-1} \mathrm{yr}^{-1}$ for total emission during the year 2006 , dominated by $\mathrm{NH}_{3}$ volatilization $(72 \%)$ and biogenic emission from soils (17\%), whereas emissions from biomass burning and domestic fires accounts for $11 \%$ only. The deposition budget is however slightly underestimated, 

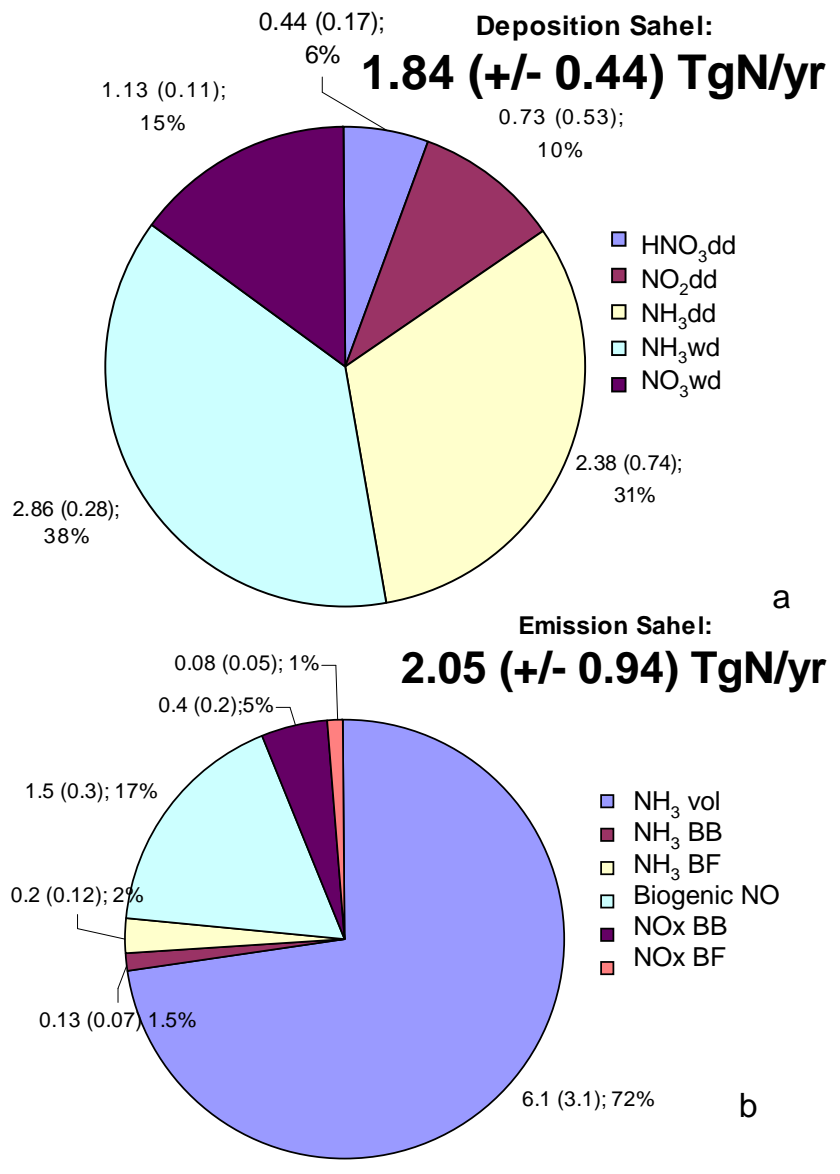

Fig. 8. Mean repartition of emission (using $30 \%$ for $\mathrm{NH}_{3}$ volatilization rate) and deposition (oxidized and reduced) $\mathrm{N}$ fluxes, scaled up at the Sahelian region $\left(2.4\right.$ millions $\left.\mathrm{km}^{2}\right)$. Given as absolute value (relative uncertainty); contribution in \%

because organic nitrates are not taken into account in the wet deposition.

If we make the reasonable assumption that dry savanna is representative of the main Sahelian vegetation type, we can scale up those fluxes to the Sahelian region: the estimated emission in the Sahel could be $2.0( \pm 0.9) \mathrm{TgN} / \mathrm{yr}$, whereas estimated deposition would be $1.8( \pm 0.4) \mathrm{TgN} / \mathrm{yr}$. The uncertainties are numerous, but they are linked to necessary assumptions considering the small amount of data available in this region. Uncertainties have been calculated for each contribution of the budget, and are linked to the concentration measurements (in gas and rain), to the dry deposition velocities estimated from modeling, to the lack of validation data in the Sahel, to the estimated livestock population in the Sahel, to the ANN algorithm estimate of biogenic NO, to the assumption that deposition fluxes are calculated with the inferential method, and to the fact that only three $\mathrm{N}$ compounds are used in the deposition calculation (Organic Nitrogen not taken into account). The highest uncertainties are found for
$\mathrm{NO}_{2}$ dry deposition flux, for the $\mathrm{NH}_{3}$ volatilization flux and for the fire emissions. However, only the $\mathrm{NH}_{3}$ volatilization flux uncertainty has a significant impact on the overall budget, and could change significantly the amount of released Nitrogen in the atmosphere. The overall uncertainty in emission is $45 \%$, and $25 \%$ in deposition. We have assumed that long range transport of nitrogen compounds did not influence local deposition (except wet deposition) at the three studied stations. If applied to other regions, this assumption has to be carefully re-considered. This work does not claim to be totally exhaustive, but wants to bring a supplementary knowledge for the unknown Sahel region. These values show that dry savanna ecosystems in the Sahel have to be taken into account for the $\mathrm{N}$ budget calculation. A lot of work remains to improve this budget however. The improvement of the ANN module for suitability in other West African ecosystems (wet savannas, forests) is foreseen in future research studies, as well as planning field campaigns in the Sahel to validate our deposition flux calculations.

Furthermore, in order to validate the assumptions given in this study, in collaboration with specialized teams, further measurements are needed to improve the biogeochemical description of the soils in arid and semi-arid regions. This is needed to better understand the strong release of $\mathrm{N}$ compounds at the beginning of the wet season, despite their low $\mathrm{N}$ content, and to improve the quantification of $\mathrm{N}$ release to the atmosphere.

This study, involving original and unique data from remote and seldom explored regions, will be extended to other West African ecosystems in the future.

Acknowledgements. Based on a French initiative, AMMA was built by an international scientific group and is currently funded by a large number of agencies, especially from France, the United Kingdom, the United States, and Africa. It has been the beneficiary of a major financial contribution from the European Community Sixth Framework Research Programme. Detailed information on scientific coordination and funding is available on the AMMA International Web site at www.amma-international.org. This work was funded by the EU and by the UK Natural Environment Research Council through the AMMA-UK Consortium grant and the National Centre for Atmospheric Science.

Edited by: F. Dentener

\section{References}

Adon, M., Galy-Lacaux, C., Yoboué, V., Delon, C., Lacaux, J. P., Castera, P., Gardrat, E., Pienaar, J., Al Ourabi, H., Laouali, D., Diop, B., Sigha-Nkamdjou, L., Akpo, A., Tathy, J., Lavenu, F., and Mougin, E.: Long-term measurements of sulphur dioxide, nitrogen dioxide, ammonia, nitric acid and ozone in Africa using passive samplers, Atmos. Chem. Phys. Discuss., 10, 4407-4461, 2010, http://www.atmos-chem-phys-discuss.net/10/4407/2010/.

Ali, A., Lebel, T., and Amani, A.: Invariance in the spatial structure of Sahelian rain fields at climatological scales, J. Hydrometeor., 4, 996-1011, 2003. 
Assamoi E. M. and Liousse, C.: Focus on the impact of two wheel vehicles on African combustion aerosols emissions, Atmos. Environ., under revision, 2010.

Andreae, M. O. and Merlet, P.: Emission of trace gases and aerosols from biomass burning, Global Biogeochem. Cy., 15, 955-966, 2001.

Aubréville, A.: Climats, forêts et désertification de l'Afrique tropicale, Soc. Ed. Géogr. Marit. et col., Paris (in french), 351 pp., 1949.

Austin, A. T., Yahdjian, L., Stark, J. M., Belnap, J., Porporato, A., Norton, U., Ravetta, D. A., and Schaeffer, S. M.: Water pulses and biogeochemical cycles in arid and semi arid ecosystems, Oecologia, 141, 221-235, 2004.

Baer, M. and Nester, K.: Parametrization of trace gas dry deposition velocities for a regional mesoscale diffusion model, Ann. Geophys., 10, 912-923, 1992,

http://www.ann-geophys.net/10/912/1992/.

Barger, N. N., Belnap, J., Ojima, D. S., and Mosier, A.: NO gas loss from biologically crusted soils in Canyonlands National Park, Utah, Biogeochem., 75, 373-391, 2005.

Boone A., De Rosnay, P., Balsamo, G., Beljaars, A., Chopin, F., Decharme, B., Delire, C., Ducharne, A., Gascoin, S., Grippa, M., Guichard, F., Gusev, Y., Harris, P., Jarlan, L., Kergoat, L., Mougin, E., Nasonova, O., Norgaard, A., Orgeval, T., Ottl, C., Poccard-Leclerq, I., Polcher, J., Sandholt, I., Saux-Picart, S., Taylor, C., and Xue, Y.: The AMMA Land Surface Model Intercomparison Project (ALMIP), Bull. Amer. Meteor. Soc., 18651880, doi:10.1175/2009BAMS2786.1, 2009.

Bouwman, A. F., Lee, D. S., Asman, W. A. H., Dentener, F. J., Van Der Hoek, K. W., and Olivier, J. G. J.: A Global High-Resolution Emission Inventory for Ammonia, Global Biogeochem. Cy., 11(4), 561-587, 1997.

Bouwman, A. F. and Van Der Hoek, K. W.: Scenarios of animal waste production and fertilizer use and associated ammonia emission for the developping countries, Atmos. Env., 31(24), 4095-4102, 1997.

Bouwman, A. F., Boumans, L. J., and Batjes, N. H.: Estimation of global $\mathrm{NH}_{3}$ volatilization loss from synthetic fertilizers and animal manure applied to arable lands and grasslands, Glob. Biogeochem. Cy., 16(2), 1024, doi:10.1029/2000GB001389, 2002a.

Bouwman, A. F., Boumans, L. J. M., and Batjes, N. H.: Modeling global annual $\mathrm{N}_{2} \mathrm{O}$ and $\mathrm{NO}$ emissions from fertilized fields, Glob. Biogeochem. Cy., 16(4), 1080, doi:10.1029/2001GB001812, 2002b.

Butterbach-Bahl, K., Kock, M., Willibald, G., Hewett, B., Buhagiar, S., Papen, H., and Kiese, R.: Temporal variations of fluxes of $\mathrm{NO}, \mathrm{NO}_{2}, \mathrm{~N}_{2} \mathrm{O}, \mathrm{CO}_{2}$, and $\mathrm{CH}_{4}$ in a tropical rain forest ecosystem, Global Biogeochem. Cy., 18, GB3012, doi:10.1029/2004GB002243, 2004.

Carmichael G. R., Ferm, M., Thongboonchoo, N., Woo, J.-H., Chan, L. Y., Murano, K., Viet, P. H., Mossberg, C., Bala, R., Boonjawat, J., and Lacaux, J. P.: Measurements of sulfur dioxide, ozone and ammonia concentrations in Asia, Africa, and South America using passive samplers, Atmos. Environ., 37, 1293-1308, 2003.

Vila-Guerau de Arellano, J. and Duynkerke, P. G.: influence of chemistry on the flux-gradient relationships for the $\mathrm{NO}-\mathrm{O}_{3}-\mathrm{NO}_{2}$ system, Bound. Lay. Meteorol., 61, 375-387, 1992.

Davidson, E. A. and Kingerlee, W.: A global inventory of nitric oxide emissions from soils, Nutr. Cy. Agroecosyst., 48, 37-50, 1997.

Delon, C., Serça, D., Boissard, C., Dupont, R., Dutot, A., Laville, de Rosnay, P., and Delmas, R.: Soil NO emissions modelling using artificial neural network, Tellus B, 59B, 502-513, 2007.

Delon, C., Reeves, C. E., Stewart, D. J., Sera, D., Dupont, R., Mari, C., Chaboureau, J.-P., and Tulet, P.: Biogenic nitrogen oxide emissions from soils-impact on $\mathrm{NO}_{\mathrm{X}}$ and ozone over West Africa during AMMA (African Monsoon Multidisciplinary Analysis): modelling study, Atmos. Chem. Phys., 8, 2351-2363, 2008, http://www.atmos-chem-phys.net/8/2351/2008/.

Dentener, F., Drevet, J., Lamarque, J. F., Bey, I., Eickhout, B., Fiore, A. M., Hauglustaine, D., Horowitz, L. W., Krol, M., Kulshrestha, U. C., Lawrence, M., Galy-Lacaux, C., Rast, S., Shindell, D., Stevenson, D., Van Noije, T., Atherton, C., Bell, N., Bergman, D., Butler, T., Cofala, J., Collins, B., Doherty, R., Ellingsen, K., Galloway, J., Gauss, M., Montanaro, V., Mller, J. F., Pitari, G., Rodriguez, J., Sanderson, M., Solmon, F., Strahan, S., Schultz, M., Sudo, K., Szopa, S., and Wild, O.: Nitrogen and sulfur deposition on regional and global scales: A multimodel evaluation, Global Biogeochem. Cy., 20(4), GB4003, doi:10.1029/2005GB002672, 2006.

De Rosnay P., Drusch, M., Boone, A., Balsamo, G., Decharme, B., Harris, P., Kerr, Y., Pellarin, T., Polcher, J., and Wigneron, J.-P.: AMMA Land Surface Model Intercomparison Experiment coupled to the Community Microwave Emission Model: ALMIP-MEM, J. of Geophys. Res., 114, D05108, doi:10.1029/2008JD010724, 2009.

Diallo and Gjessing, Natural resources management: Morphopedology in Gourma region. SSE Research program MaliNorway (in French), CNRST-IER-Oslo University (Norway), 119, 1999.

Duyzer J. and Fowler, D.: Modelling land atmosphere exchange of gaseous oxides of nitrogen in Europe, Tellus, 46B, 353-372, 1994.

Erisman, J., and Baldocchi, D.: Modelling dry deposition of so2, Tellus, Ser. B, 46, 159-171, 1994.

Ferm, M., Lindskorg, A., Svanberg, P. A., and Boström, C. A.: New measurement technique for air pollutants (in Swedish), Kem. Tidskr. 1, 30-32, 1994.

Ferm, M. and Rodhe, H.: Measurements of air concentrations of $\mathrm{SO}_{2}, \mathrm{NO}_{2}$ and $\mathrm{NH}_{3}$ at rural sites in Asia, J. Atmos. Chem., 27, 17-29, 1997.

Galbally I., Kirstine, W. V., Meyer, C. P., and Wang, Y. P.: Soilatmosphere trace gas exchange in semiarid and arid zones, J. Environ. Qual. 37, 599-607, 2008.

Galloway, J. N. and Cowling, E. B.: Reactive nitrogen and the world: 200 years of change, Ambio, 31, 64-71, 2002.

Galloway, J. N., Dentener, F. J., Capone, D. G., Boyer, E. W., Howarth, R. W., Seitzinger, S. P., Asner, G. P., Cleveland, C. C., Green, P. A., Holland, E. A., Karl, D. M., Michaels, A. F., Porter, J. H., Townsend, A. R., and Sarty, C. J.: Nitrogen cycles: past, present, and future, Biogeochemistry, 70, 153-226, 2004.

Galloway, J. N., Townsend, A. R., Erisman, J. W., Bekunda, M., Cai, Z., Freney, J. R., Martinelli, L. A., Seitzinger, S. P., and Sutton, M. A.: Transformation of the Nitrogen Cycle: Recent Trends, Questions, and Potential Solutions, Science, 320, 889892, 2008.

Galy-Lacaux C. and Modi, A. I.: Precipitation chemistry in the Sa- 
helian savanna in Niger, Africa, J. Atmos. Chem., 30, 319-343, 1998.

Galy-Lacaux C., Carmichael, G. R., Song, C. H., Lacaux, J. P., Al Ourabi, H., and Modi, A. I.: Heterogeneous processes involving nitrogenous compounds and Saharan dust inferred from measurements and model calculations, J. Geophys. Res., 106(D12), 12559-12578, 2001.

Galy-Lacaux C., Al Ourabi, H., Galloway, J., Lacaux, J. P., Mphepya, J., Pienaar, K., Pont, V., Sigha, L., and Yobou, V.: Dry and Wet Atmospheric Nitrogen Deposition in Africa, IGACtivities Newsletter of the International Global Atmospheric Chemistry Project, DEBITS Special Issue 27, 2003.

Galy-Lacaux C., Laouali, D., Descroix, L., Gobron, N., and Liousse, C.: Long term precipitation chemistry and wet deposition in a remote dry savanna site in Africa (Niger), Atmos. Chem. Phys., 9, 1579-1595, 2009,

http://www.atmos-chem-phys.net/9/1579/2009/.

Geiger B., Meurey, C., Lajas, D., Franchistǵuy, L., Carrer, D., and Roujean, J.-L.: Near real-time provision of downwelling shortwave radiation estimates derived from satellite observations, Meteor. Appl., 15, 411-420, 2008.

Hansen, M. C., Defries, R. S., Townshend, J. R. G., and Sohlberg, R.: Global land cover classification at $1 \mathrm{~km}$ spatial resolution using a classification tree approach. Int. J. Remote Sens., 21, 13311364, 2000.

Hanson P.J. and S.E. Lindberg, Dry deposition of reactive nitrogen compounds: a review of leaf, canopy and non-foliar measurements, Atmos. Environ., 25A, 8, 1615-1634, 1991.

Hill, K. A., Shepson, P. B., Galbavy, E. S., and Anastasio, C.: Measurement of wet deposition of inorganic and organic nitrogen in a forest environment, J. of Geophys. Res., 110, G02010, doi:10.1029/2005JG000030, 2005.

Huffman G. J., Adler, R. F., Bolvin, D. T., Gu, G., Nelkin, E. J., Bowman, K. P., Hong, Y., Stocker, E. F., and Wolff, D. B.: The TRMM Multi-satellite Precipitation Analysis: QuasiGlobal, Multi-Year, Combined-Sensor Precipitation Estimates at Fine Scale, J. Hydrometeor., 8, 38-55, 2007.

Jaeglé, L., Martin, R. V., Chance, K., Steinberger, L., Kurosu, T. P., Jacob, D. J., Modi, A. I., Yoboué, V., Sigha-Nkamdjou, L., and Galy-Lacaux, C.: Satellite mapping of rain-induced nitric oxide emissions from soils, J. Geophys. Res., 109, D21310, doi:10.1029/2003JD004406, 2004.

Jain, A. K.: Global estimation of CO emissions using three sets of satellite data for burned area, Atmos. Environ., 41, 6931-6940, 2007.

Jin, L. Shao, M., Zeng, L., Zhao, D., and Tang, D.: Estimation of dry deposition fluxes of major inorganic species by canopy throughfall approach, Chinese Sci. Bull., 51(15), 1818-1823, 2006.

Johansson D., H. Rodhe, and E. Sanhueza, Emission of NO in a tropical savanna and a cloud forest during the dry season, J. Geophys. Res., 93(D6), 7180-7192, 1988.

Junker C. and Liousse, C.: A Global Emission Inventory of Carbonaceous Aerosol including Fossil Fuel and Biofuel sources for the Period 1860-1997, Atmos. Chem. Phys., 8, 1-13, 2008, http://www.atmos-chem-phys.net/8/1/2008/.

Kramm, G., Dlugi, R., Dollard, G. J., Foken, T.,Molders, N., Muller, H., Seiler, W., and Sievering, H.: On the dry deposition of ozone and reactive nitrogen species, Atmos. Environ., 29(21),
3209-3231, 1995.

Kristensen L., Lenshow, D. H., Gurarie, D., and Jensen, N. O.: A simple model for vertical transport of reactive species in the convective atmospheric boundary layer, Bound. Lay. Meteorol., 134, 195-221, 2010.

Le Roux, X., Abbadie, L., Lensi, R., and Serça, D.: Emission of nitrogen monoxide from African tropical ecosystems: Control of emission by soil characteristics in humid and dry savannas of West Africa, J. Geophys. Res., 100, 23133-23142, 1995.

Liousse C., Guillaume, B., Gregoire, J. M., Mallet, M., GalyLacaux, C., Poirson, A., Solmon, F., Pont, V., Mariscal, A., Dungal, L., Rosset, R., Yobou, V., Bedou, X., Sera, D., Konar, A., Granier, C., and Mieville, A.: African Aerosols Modelling during the EOP-AMMA campaign with updated biomass burning emission inventories, submitted to Atmos. Chem. Phys. Discuss, 2010.

Loveland, T. R., Reed, B. C., Brown, J. F., Ohlen, D. O., Zhu, Z., Yang, L., and Merchant, J.: Global Land Cover Characteristics Database (GLCCD) Version 2.0. Available online at http://edcdaac.usgs.gov/glcc/globdoc2_0.html, 2000.

Ludwig J., L.T. Marufu, B. Huber, M.O. Andreae and G. Helas, Domestic combustion of biomass fuels in developing countries: a major source of atmospheric pollutants, J. of Atmos. Chem., 44, 23-37, 2003.

Mari, C. H., Cailley, G., Corre, L., Saunois, M., Attie, J. L., Thouret, V., and Stohl, A.: Tracing biomass burning plumes from the Southern Hemisphere during the AMMA 2006 wet season experiment, Atmos. Chem. Phys. Discuss., 7, 17339-17366, 2008, http://www.atmos-chem-phys-discuss.net/7/17339/2008/.

Martins, J. J., Dhammapala, R. S., Lachmann, G., Galy-Lacaux, C., and Pienaar, J. J.: Long-term measurements of sulphur dioxide, nitrogen dioxide, ammonia, nitric acid and ozone in southern Africa using passive samplers, South Afr. J. Sci., 103, 336-342, 2007.

Masson, V., Champeaux, J.-L., Chauvin, F., Meriguet, C. and Lacaze, R.: A global database of land surface parameters at 1$\mathrm{km}$ resolution in meteorological and climate models. J. Climate, 16(9), 1261-1282, 2003.

Matt, D. R. and Meyers, T. P.: On the use of the inferential technique to estimate dry deposition of $\mathrm{SO}_{2}$, Atmos. Env., 27A, 4, 493-501, 1993.

Mayaux, P., Bartholom, E., Massart, M., Van Cutsem, C., Cabral, A., Nonguierma, A., Diallo, O., Pretorius, C., Thompson, M., Cherlet, M., Pekel, J.-F., Defourny, P., Vasconcelos, M., Di Gregorio, A., Fritz, S., De Grandi, G., Elvidge, C., Vogt, P., and Belward, A.: Global Land Cover 2000 Project, European Commission Joint Research Centre, http://www.gvm.jrc.it/glc2000, 2003.

Meixner, F. X. and Yang, W. X.: Biogenic emissions of nitric oxide and ditrous oxide from arid and semi-arid land, Dryland Ecohydrology, edited by: DÓdoroco, P. and Porporato, A., by Kluwer Academic Publishers B.V., Dordrecht, The Netherlands, 23-46, 2004.

Michel C., Liousse, C., Grégoire, J.-M., Tansey, K., Carmichael, G. R., and Woo, J.-H.: Biomass burning emissions inventory from burnt area data given by SPOT-Vegetation satellite for TRACE-P and ACE-Asia case studies, J. of Geophys. Res., 110, D09304, doi:10.1029/2004JD005461, 2005.

Mieville, A., Granier, C., Liousse, C., Guillaume, B., Mouillot, F., 
Lamarque, J. F., Grégoire, J. M., and Pétron, G.: Emissions of gases and particles from biomass burning during the 20th century using satellite data and an historical reconstruction, Atmos. Environ., in press, 2010.

Mosier A., Kroeze, C., Nevison, C., Oenema, O., Seitzinger, S., and van Cleemput, O.: Closing the global $\mathrm{N}_{2} \mathrm{O}$ budget: nitrous oxide emissions through the agricultural nitrogen cycle, Nutr. Cy. Agroecosys., 52, 225-248, 1998.

Mougin, E., Hiernaux, P., Kergoat, L., Grippa, M., De Rosnay, P., Timouk, F., Le Dantec, V., Demarez, V., Arjounin, M., Lavenu, F., Soumaguel, N., Ceschia, E., Mougenot, B., Baup, F., Frappart, F., Frison, P. L., Gardelle, J., Gruhier, C., Jarlan, L., Mangiarotti, S., Sanou, B., Tracol, Y., Guichard, F., Trichon, V., Diarra, L., Soumaré, A., Koité, M., Dembélé, F., Lloyd, C., Hanan, N. P., Damesin, C., Delon, C., Serça, D., Galy-Lacaux, C., Seghiéri, J., Becerra, S., Dia, H., Gangneron, F., and Mazzega, P.: The AMMA-CATCH Gourma observatory site in Mali: Relating climatic variations to changes in vegetation, surface hydrology, fluxes and natural resources, J. Hydrology, AMMA-CATCH Special issue, 375, 14-33, 2009.

Munger J. W., Fan, S.-M., Bakwin, P. S., Goulden, M. L., Goldstein, A. H. Colman, A. S., and Wofsy, S. C.: Regional budgets for nitrogen oxides from continental sources: Variations of rates for oxidation and deposition with season and distance from source regions, J. Geophys. Res., 103(D7), 8355-8368, 1998.

Noilhan, J. and Mahfouf, J.-F.: The ISBA land surface parameterization scheme. Glob. Planet. Change, 13, 145-159, 1996.

Otter, L. B., Yang, W. X., Scholes, M. C. and Meixner, F. X.: Nitric oxode emissions from a southern african savanna, J. of Geophys. Res, 104(D15), 18471-18485, 1999.

Pineda Rojas A. L. and Venegas, L. E.: Atmospheric deposition of nitrogen emitted in the Metropolitan Area of Buenos Aires to coastal waters of de la Plata River, Atmos. Environ., 43, 13391348, 2009.

Potter, C. S., Matson, P. A., Vitousek, P. M., and Davidson, E. A.: Process modelling of controls on nitrogen trace gas emissions from soils worldwide, J. Geophys. Res., 101, 1361-1377, 1996.

Sauvage, B., Thouret, V., Cammas, J.-P., Brioude, J., Nedelec, P., and Mari, C.: Meridional ozone gradients in the African upper troposphere, Geophys. Res. Lett. 34(3), 03817, doi:10.1029/2006GL028542, 2007.

Schlecht, E., Fernandez-Rivera, S., and Hiernaux, P.: Timing, size and $\mathrm{N}$-concentration of faecal and urinary excretions in cattle, sheep and goats - can they be used for better manuring of cropland?, edited by: Renard, G., Neef, A., Becker, K., and von Oppen, M., Soil fertility Management in West AfricanLand Use Systems. Margraf Verlag, Weikersheim, Germany, 361-368, 1998.

Schlecht E. and Hiernaux, P.: Beyond adding up inputs and outputs: process assessment and upscaling in modelling nutrient flows, Nutr. Cy. Agroecosys., 70, 303-319, 2004.

Schlecht E., Hiernaux, P., Achard, F., and Turner, M. D.: Livestock related nutrient budgets within village territories in western Niger, Nutr. Cy. Agroecosys., 68, 199-211, 2004.

Seinfeld J. H. and Pandis, S. N.: Atmospheric Chemistry and Physics: from air pollution to climate change, A WileyInterscience publication, USA, 1326 pp., 1998.

Serça, D., Delmas, R., Le Roux, X., Parsons, D. A. B., Scholes, M. C., Abbadie, L., and co-authors: Comparison of nitrogen monox- ide emissions from several African tropical ecosystems and influence of season and fire, Global Biogeochem. Cy., 12, 637-651, 1998.

Shen J. L., Tang, A. H., Liu, X. J., Fangmeier, A., Goulding, K. T. W., and Zhang, F. S.: High concentrations and dry deposition of reactive nitrogen species at two sites in the North China Plain, Environ. Pollut. 157, 3106-3113, 2009.

Sigha-Nkamdjou, L., Galy-Lacaux, C., Pont, V., Richard, S., Sighoumnou, D., and Lacaux, J.-P.: Rainwater chemistry and wet deposition over the equatorial forested ecosystem of Zoetele (Cameroon), J. Atmos. Chem., 46, 173-198, 2003.

Stroppiana, D., Brivio, P. A., Grégoire, J.-M., Liousse, C., Guillaume, B., Granier, C., Mieville, A., and Chin, M.: Comparison of global monthly $\mathrm{CO}$ emission maps derived from remotely sensed burned area datasets, Atmos. Chem. Phys., submitted, 2010.

Sutton, M. A., Burkhardt, J. K., Guerin, D., Nemitz, E., and Fowler, D.: Development of resistance models to describe measurements of bi-directional ammonia surface-atmosphere exchange, Atmos. Environ., 32(3), 473-480, 1998.

Sutton, M. A., Nemitz, E., Erisman, J. W., Beier, C., Butterbach Bahl, K., Cellier, P., de Vries, W., Cotrufo, F., Skiba, U., Di Marco, C., Jones, S., Laville, P., Soussana, J. F., Loubet, B., Twigg, M., Famulari, D., Whitehead, J., Gallagher, M. W., Neftel, A., Flechard, C. R., Herrmann, B., Calanca, P. L., Schjoerring, J. K., Daemmgen, U., Horvath, L., Tang, Y. S., Emmett, B. A., Tietema, A., Peuelas, J., Kesik, M., Brueggemann, N., Pilegaard, K., Vesala, T., Campbell, C. L., Olesen, J. E., Dragosits, U., Theobald, M. R., Levy, P., Mobbs, D. C., Milne, R., Viovy, N., Vuichard, N., Smith, J. U., Smith, P., Bergamaschi, P., Fowler, D., and Reis, S.: Challenges in quantifying biosphere-atmosphere exchange of nitrogen species, Env. Poll., 150, 125-139, 2007.

Tansey, K., Grégoire, J. M., Defourny, P., Leigh, R., Pekel, J. F., Van Bogaert, E., and Bartholomé, E.: A new, global, multi-annual (2000-2007) burnt area product at $1 \mathrm{~km}$ resolution, Geophys. Res. Lett., 35, L01401, doi:10.1029/2007GL031567, 2008.

Tost H., Jöckel, P., Kerkweg, A., Pozzer, A., Sander, R., and Lelieveld, J.: Global cloud and precipitation chemistry and wet deposition: tropospheric model simulations with ECHAM5/MESSy1, Atmos. Chem. Phys., 7, 2733-2757, 2007, http://www.atmos-chem-phys.net/7/2733/2007/.

Trebs, L., Lara, L. L., Zeri, L. M. M., Gatti, L. V., Artaxo, P., Dlugi, R., Slanina, J., Andreae, M. O., and Meixner, F. X.: Dry and wet deposition of inorganic nitrogen compounds to a tropical pasture site (Rondnia, Brazil), Atmos. Chem. Phys., 6, 447-469, 2006, http://www.atmos-chem-phys.net/6/447/2006/.

Vlek, P. L. G., Fillery, I. R. P., and Burford, J. R.:Accession, transformation, and loss of nitrogen in soils of the arid region, Plant Soil, 58, 133-175, 1981.

Wesely, M. L. and Hicks, B. B.: Some factors that affect the deposition rates of sulfur dioxide and similar gases on vegetation, J. Poll. Control Assoc., 27, 1110-1117, 1977.

Wesely, M. L.: Parameterization of surface resistances to gaseous dry deposition in regional-scale numerical models, Atmos. Environ., 23, 1293-1304, 1989.

Whelpdale, D. M., Summers, P. W., and Sanhueza, E.: A global overview of atmospheric acid deposition fluxes, Environ. Monitor. Assess., 48, 217-247, 1997. 
Whitall D., Hendrickson, B., and Paerl, H.: Importance of atmospherically deposited nitrogen to the annual nitrogen budget of the Neuse River estuary, North Carolina, Environ. Int., 29(2-3), 393-399, 2003.

White, F.: La végétation de l'Afrique. Mémoire accompagnant la carte de végétation de l'Afrique UNESCO/AETFAT/UNSO.ORSTOM et UNESCO (in french), Paris, collection Recherches sur les ressources naturelles, 20, 384 pp., 1986.

Williams, E. J., Guenther, A., and Fehsenfeld, F. C.: An inventory of nitric oxide emissions from soils in the United States, J. Geophys. Res., 97, 7511-7519, 1992.

Yan, X., Ohara, T., and Akimoto, H.: Statistical modelling of global soil NOx emissions, Global Biogeochem. Cy., 19, GB3019, doi:10.1029/2004GB002276, 2005.

Yienger, J. J. and Levy II, H.: Empirical model of global soil biogenic $\mathrm{NO}_{\mathrm{x}}$ emissions, J. Geophys. Res., 100, 11447-11464, 1995.

Yoboué, V., Galy-Lacaux, C., Lacaux, J. P., and Sibué, S.: Rainwater Chemistry and Wet Deposition over the Wet Savanna Ecosystem of Lamto (Côte d'Ivoire), J. Atmos. Chem., 52, 117-141, 2005.
Zhang L., Gong, S., Padro, J., and Barrie, L.: A size-segregated particle dry deposition scheme for an atmospheric aerosol module, Atmos. Environ., 35, 549-560, 2001.

Zhang, L., Brook, J. R., Vet, R., Wiebe, A., Mihele, C., Shaw, M., OBrien, J. M., and Iqbal, S.: Estimation of contributions of $\mathrm{NO}_{2}$ and PAN to total atmospheric deposition of oxidized nitrogen across Eastern Canada, Atmos. Environ., 39, 7030-7043, 2005.

Zhang L., J.R. Brook and R. Vet, A revised parameterization for gaseous dry deposition in air-quality models, Atmos. Chem. Phys. 3, 2067-2082, 2003.

Zhang, L., Vet, R., OBrien, J. M., Mihele, C., Liang, Z., and Wiebe, A.: Dry deposition of individual nitrogen species at eight Canadian rural sites, J.Geophys. Res., vol 114, D02301, doi:10.1029/2008JD010640, 2009. 